PNL-5079

UC-41

\title{
U.S. Department of Energy Quality Assessment Program Data Evaluation Report
}

R. E. Jaquish

R. R. Kinnison

April 1984

Prepared for the U.S. Department of Energy under Contract DE-AC06-76RLO 1830

Pacific Northwest Laboratory

Operated for the U.S. Department of Energy by Battelle Memorial Institute 


\section{DISCLAIMER}

This report was prepared as an account of work sponsored by an agency of the United States Government. Neither the United States Government nor any agency thereof, nor any of their employees, makes any warranty, express or implied, or assumes any legal liability or responsibility for the accuracy, completeness, or usefulness of any information, apparatus, product, or process disclosed, or represents that its use would not infringe privately owned rights. Reference herein to any specific commercial product, process, or service by trade name, trademark, manufacturer, or otherwise, does not necessarily constitute or imply its endorsement, recommendation, or favoring by the United States Government or any agency thereof. The views and opinions of authors expressed herein do not necessarily state or reflect those of the United States Government or any agency thereof.

\section{PACIFIC NORTHWEST LABORATORY operated by \\ BATTELLE \\ for the \\ UNITED STATES DEPARTMENT OF ENERGY under Contract DE-AC06-76RLO 1830}

\begin{tabular}{|c|c|}
\hline \multicolumn{2}{|c|}{$\begin{array}{l}\text { Printed in the United States of America } \\
\text { Available from } \\
\text { National Technical Information Service } \\
\text { United States Department of Commerce } \\
5285 \text { Port Royal Road } \\
\text { Springfield, Virginia } 22161\end{array}$} \\
\hline \multicolumn{2}{|c|}{$\begin{array}{l}\text { NTIS Price Codes } \\
\text { Microfiche A01 }\end{array}$} \\
\hline \multicolumn{2}{|c|}{ Printed Copy } \\
\hline Pages & $\begin{array}{l}\text { Price } \\
\text { Codes }\end{array}$ \\
\hline $001-025$ & $\mathrm{~A} 02$ \\
\hline $026-050$ & $\mathrm{~A} 03$ \\
\hline $051-075$ & A04 \\
\hline $076-100$ & A05 \\
\hline $101-125$ & A06 \\
\hline $126-150$ & $\mathrm{~A} 07$ \\
\hline $151-175$ & $\mathrm{~A} 08$ \\
\hline $176-200$ & A09 \\
\hline $201-225$ & $\mathrm{~A} 010$ \\
\hline $226-250$ & $\mathrm{~A} 011$ \\
\hline $251-275$ & $\mathrm{~A} 012$ \\
\hline $276-300$ & $\mathrm{~A} 013$ \\
\hline
\end{tabular}


PNL -5079

UC-41

U.S. DEPARTMENT OF ENERGY QUALITY ASSESSMENT PROGRAM

DATA EVALUATION REPORT

R. E. Jaquish

R. R. Kinnison

Apri 11984

Prepared for the U.S. Department of Energy under Contract DE-AC06-76RLO 1830

Pacific Northwest Laboratory Richland, Washington 99352 



\section{SUMMARY}

This report summarizes and evaluates the results from the analysis of the Quality Assessment Program (OAP) samples submitted to the OAP participants in November 1983. The data were evaluated using the Environmental Measurements Laboratory (EML) values as the known values and 3-sigma control limits previously established for the OAP program. Descriptive statistics and probability plots were developed using the MINITAB statistical program.

This report reviews the results submitted by 26 participating laboratories for 49 different radionuclide-media combinations. The participants reported 419 results, and of these 350 or $84 \%$ were within control 1 imits.

For results that are outside the control 1 imits as indicated in Table 3 of the report, participants should review their results for possible procedural, calibration or reporting errors. It is not possible to make definite conclusions about sources of analytical problems from this one set of data; however, there were some areas where there were differences between the participants and the known value. These were in the areas of ${ }^{239} \mathrm{Pu}$ in air filters and water, ${ }^{40} \mathrm{~K}$ in soil and total uranium in vegetation. There were also excessive numbers of outliers for the $239 \mathrm{Pu}$ in soil analysis. These situations will be reviewed further in subsequent reports. 


\section{$\cdot$}




\section{IABLE OF CONJENTS}

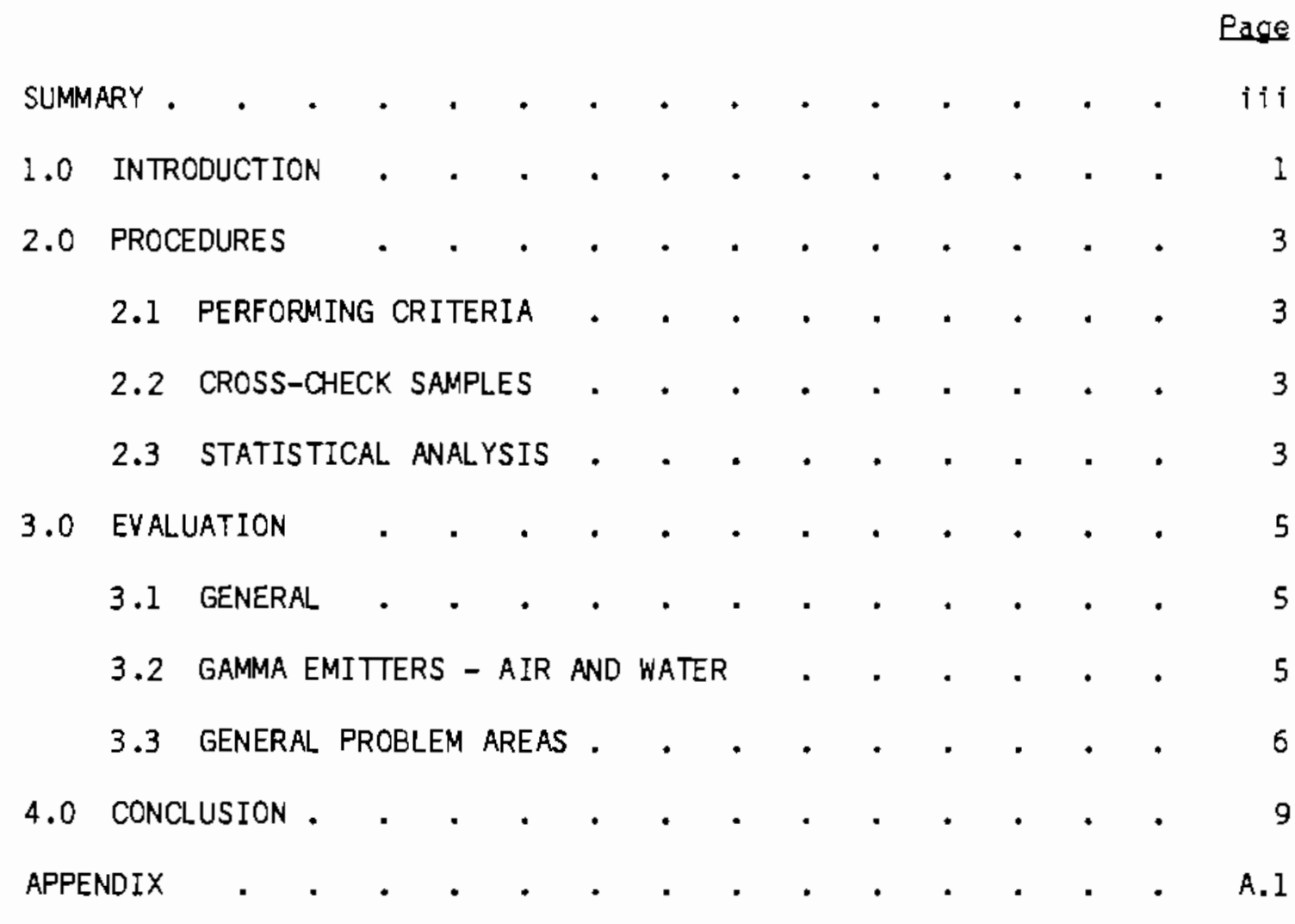




\section{IABLES}

Page

1 Coefficients of Variation and Control Limits Used for Data Evaluation . . . . . . . . 11

2 Laboratory Identification . . . . . . . . . 13

3 OAP Data Evaluation Report - Summary . . . . . . 15

4 OAP Data Evaluation Report - Laboratory

Performance Summary . . . . . . . . . . 17

5 Summary of Analysis of Gamma Emitters

in Air Filters and Water Samples. . . . . . . 21 


\subsection{INTRODUCTION}

The purpose of this report is to evaluate the results of radiochemical analysis performed on the Quality Assesment Program (QAP) test samples. This covers the results of the samples that were submitted to the participants in November 1983. The complete listing of results from all participants is reported in EML-426, "Semi-Annual Report of the Department of Energy, Operational Safety, Health and Environment Division - Ouality Assessment Program," March 1, 1984.

The DOE Environmental Measurements Laboratory (EML) conducts the Quality Assessment Program. They prepare, thoroughly characterize and distribute test samples to the participants and report the analytical resuits. This program has been in existence since 1976. To increase the utilization of the information obtained from this program to upgrade the analytical capabilities of the participating laboratories, the office of Operational Safety requested PNL to prepare an evaluation of the QAP data. It is intended that this report be a concise sumary of the resuits that clearly indicates which analyses are outside control 1 imits and need follow-up to determine reasons and take corrective action. 



\subsection{PROCEDURES}

\subsection{PERFORMANCE CRITERIA}

Before the resutts of the current QAP study were analyzed, performance criteria in terms of control imits for each type of analysis were developed. Data from previous OAP studies were analyzed using descriptive statistical methods to determine the interlaboratory precision that had been demonstrated. Precision values and control 1 imits from similar programs were also reviewed. A letter report was prepared and distributed to the $Q A$ Steering Committee and the DOE Operations Offices that described the rationale, procedures and recommended control 1 imits. These recommended control 1 imits were used for this report and are 1 isted in Table 1.

\subsection{CROSS-CHECK SAMPLES}

The EML prepares and dfstributes real or synthetic environmental samples that are thoroughly analyzed by replicate analysis. These are not standards or standard reference materlals, but are carefully homogenized samples for testing the precision and accuracy of the participating laboratories. The EML results are considered the "best estimate" of the radionuclide concentration of the samples and is used as the known value in this report.

\subsection{STATISTICAL ANALYSIS}

EML included in their report ail data from the participants that had been received by February 8, 1984. The data were provided to PNL on tape for entry into the computer. Evaluation of the data consisted of two steps: 1) comparing al 1 resuits to the control 1 imits and 2) descriptive statistics on a 11 results. Control 1 imits were established for each analysis by using the coefficient of variation in Table 2 and multiplying these by the EML known values to obtain the allowable standard devtation $\left(\sigma_{0}^{\prime}\right)$. The control 1 imits were calculated by using $3 \sigma_{0}^{\prime}$ for single analyses, $3 \sigma_{0}^{\prime} / \sqrt{2}$ for the mean of duplicates, and $3 \sigma o d \sqrt{3}$ for the mean of triplicate analysis. 
The results were evaluated to determine if they were within the known vajue plus or minus the control 1 imits. The summaries of these evaluations are given in Tables 3 and 4.

A1 1 results were analyzed on the MINITAB statistical analysis program which produced box plots and norma? probability plots for each type of analysis. The statistical parameters calculated included the mean, median, standard deviation, standard error of the mean, and maximum and minimum values. The plots displayed the properties of the data for observation of clusters and outliers. The probability plots provided information on the distribution of the data. Log normal plots were not used even though some plots suggested the data from the sample may be log-normally distributed. To keep the size of the report down, it was decided not to include all of the plots in this report, but to select one type of analys is to review in more detail and include plots for this group. For this report the group selected was the gamma emitters for air and water samples. These are included in the Appendix. Other groups will be included in subsequent reports. 


\subsection{EVALUATION}

\subsection{GENERAL}

There were 26 laboratories that submitted data on the current set of OAP samples. These laboratories with their identification codes are iisted in Table 2. A summary of the performance of laboratories submitting results on each type of analysis as compared to the control 11 mits is given in Table 3. The laboratories reported 419 measurements of which 350 or 83.5\% were within control 1 imits. Five laboratories reported 30 or more results and two reported one result. The average was 13 results per laboratory.

Table 4 shows how each laboratory compared to the control limits on each type of analysis. Results marked with a dash (-) are within control 1 imits, those with a dot $(\bullet)$ are outside control limits and those with a square (⿴) are extreme outliers. The extreme outliers are results that were outside limits by an order of magnitude or more. These may be due to a calculation or reporting error. In sone cases it was obvious that these were due to reporting in the wrong units.

Laboratories that have results outside the 3-sigma control limits should review thelr procedures and calculations on those analyses to determine the source of the problem.

\subsection{GAMMA EMITTERS - AIR AND WATER}

There were 164 reported results from the analysis of eight gamma emitters in the air filter and water samples. There were 11 results outside the 3 -sigma control limits with 4 of these being obvious errors in reporting data. The performance was similar for all eight samples with the data having a good fit to a normal distribution. The box plots, statistical parameters and nomal probability plots for the gamma emitters in air and water are included in the Appendix. Laboratories that have results that are consistently above or below the known values, even if they are with in control limits, should check their calibrations for a possible bias. 
Results that deviated from the normal distribution as seen on the probabllity plots in the Appendix should aiso be checked.

The coefficient of variation ( $C V$ ) was calculated for the gamma emitters using all data points and eliminating the extreme outliers. Using al? data the $\mathrm{CV}$ was $12.4 \%$ and with 8 out liers el iminated, the average CV was $8.0 \%$. This indicates that the $10 \%$ used as a coefficient of variation for calculating control 1 fmits is an adequate representation of the data befing analyzed.

In all cases the mean of the participants was higher than the known value. The mean deviation for a 11 gamma analyses was $+2.4 \%$. This could be due to difference in calibration standards between EML and the participants or the mean could be influenced high by a few laboratories that were biased high. This situation will be reviewed in the next study to see if the same trend exists.

\subsection{GENERAL. PROBLEM AREAS}

There were three areas where the results reported by the participants were markedly different from the known vaiue. The first of these was for $239 \mathrm{pu}$ in alr filters and water. The number of results outside the contro] 1 imits was not unusual; however, al 1 but one of the 34 reported results were below the known value. This could be an anomaly, but it appears there is a real difference. This could be due to changes in the sample conditions during transit, calibration differences or analytical differences. Loss of sample to the wall of the container is a possibility for the water sample, but not the air filters. A bias was not observed in the plutonium results for soil, tissue and vegetation; however, there was a large proportion of outliers for ${ }^{239} \mathrm{Pu}$ in soil. Subsequent results $w i 11$ be reviewed to see if this trend continues.

The second area was that the $40_{K}$ values in soil and vegetation showed the known value to be higher than the participants in all but 1 of 27 results. The results were normal ly distributed. Further review of other OAP is needed to determine if there is a calibration difference between EML and the participants. 
The third area where the known was markedly different from the participants was total uranium in vegetation in micrograms (UUG). The reported errors for the participants were high, but the results were normally distributed except for the EML result. There were oniy six participants reporting this analysis. Because of the small number of observations, no speculation as to the reason for this discrepancy is proposed.

For these three groups of data where the participants differed from the known, it is suggested that the participants and EML review their results for possible bias. 


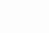

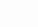

- 


\subsection{CONCLUSION}

This is the first summary and evaluation of this type prepared on the OAP data. Most of the analyses were within the expected 1 imits, except for the cases noted. The overall results of the analysis of gamma emitters in air and water showed good agreement with the known values. All values which are outside the control limits, as shown in Table 4, should be reviewed for possible procedural, calibration or reporting errors. The results of the data analysis did not suggest the need to make any changes in the control limits at this time. As additional OAP studies are evaluated, it will be possible to further define problem areas by identifying trends in the data.

Those areas where there appeared to be problems will be reviewed in more detail in the next report. 


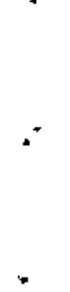

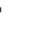




\section{IABLE 1. Coefficients of Variation and Control}

Limits Used for Data Evaluation

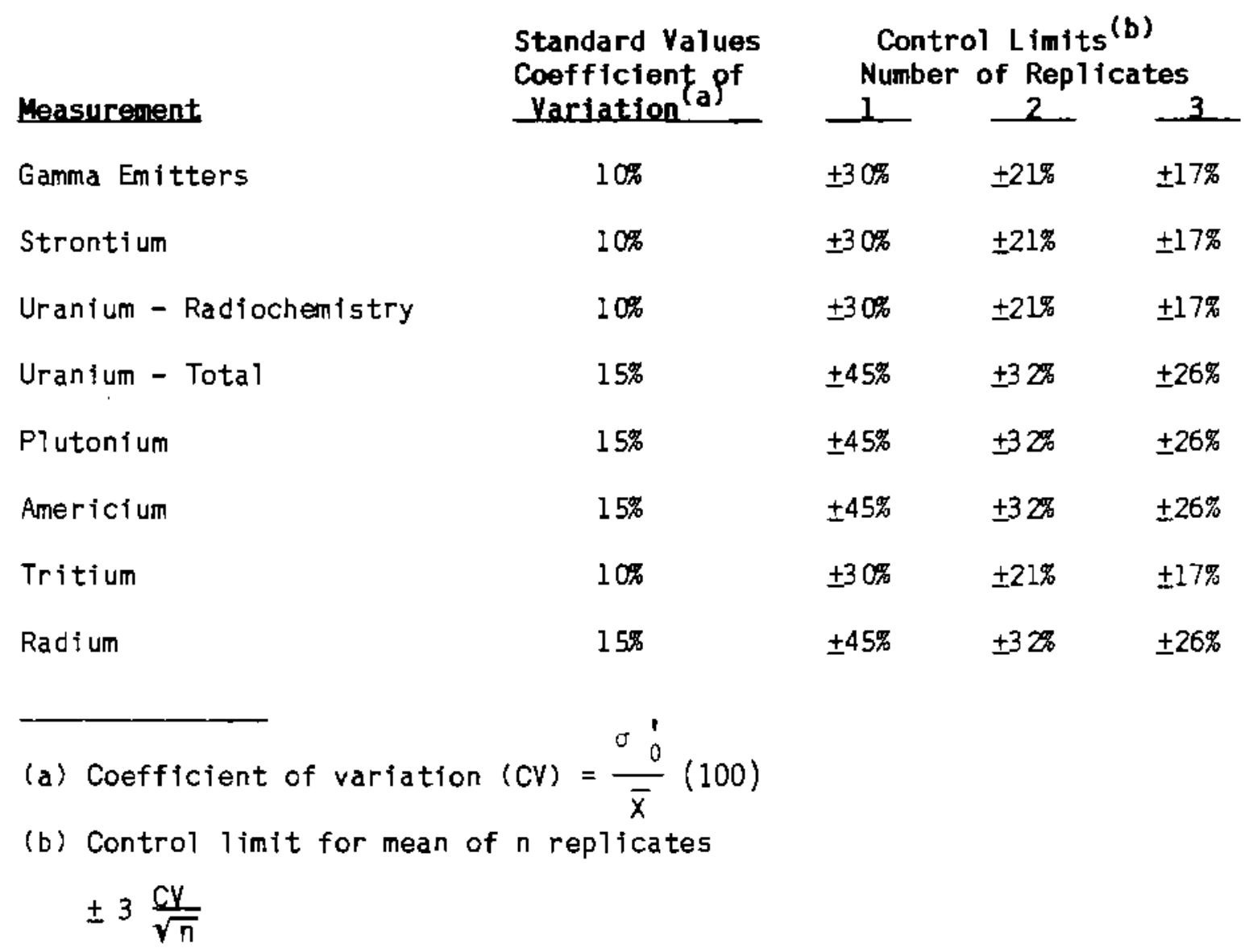

Further explanation of the derivation of the coefficients of variation and control 11 mits are presented in the letter report "Recommended Analytical Performance Criteria for QAP Sample Analysis," R. E. Jaquish and R. R. Kinnison, March 1984. 
IABLE2. Laboratory Identification

\begin{tabular}{|c|c|c|}
\hline $\begin{array}{l}\text { QAP } \\
\text { Code }\end{array}$ & ${ }_{\text {Code }}^{\text {MTB }}$ (b) & Laboratory \\
\hline$A A$ & 1 & Environmental Measurements Laboratory (Known Values) \\
\hline AN & 3 & Argonne National Laboratory \\
\hline $\mathrm{BA}$ & 4 & Bettis Atomic Power Plant \\
\hline $\mathrm{BE}$ & 5 & Bendix Field Engineering Grand Junction, Co. \\
\hline $\mathrm{BN}$ & 7 & Brookhaven National Laboratory - Robert Miltenburger \\
\hline $\mathrm{BP}$ & 8 & Pacific Nor thwest Laboratory - OSB \\
\hline $\mathrm{BZ}$ & 9 & Pacific NW Contractor (U.S. Testing, Richland, WA) \\
\hline CS & 10 & Rockwell International - Criticality Safeguards \\
\hline EN & 11 & Exxon Nuclear Idaho Company, Inc. \\
\hline FN & 12 & Fermi National Accelerator Laboratory \\
\hline GA & 13 & Goodyear Atamic Corporation \\
\hline KA & 15 & Knol 1s Atomic Power Laboratory \\
\hline LA & 16 & U. of California - Los Alamos Scientific Laboratory \\
\hline LL & 18 & U. of California - Lawrence Livermore Laboratory \\
\hline ML & 19 & Monsanto Research Corporation - Mound Facility \\
\hline NL & 20 & Nation Lead Company of Ohio \\
\hline OR & 21 & Oak Ridge National Laboratory \\
\hline PA & 22 & Mason \& Hanger-Siles Mason Company, Inc. \\
\hline PI & 23 & General Electric Company - Neutron Devices \\
\hline PR & 25 & Princeton Plasma Physics Laboratory \\
\hline RE & 24 & Reynolds Electrical Engineeríng Company, Inc. \\
\hline RF & 26 & Rockwell Internationa] - Rocky Flats \\
\hline SA & 28 & Sandia Laboratory - Organization 3311 \\
\hline SR & 30 & Savannah River Plant \\
\hline UC & 31 & Union Carbide Corporation - Nuclear Division \\
\hline UK & 32 & Union Carbide Corporation - ORGUP-K-25 \\
\hline UY & 33 & Unton Carbide Corporation - Y-12 Plant \\
\hline
\end{tabular}

(a) Code used in Quality Assessment Program Reports

(b) Numerical code used in MINITAB statistical program 

IABLE 3. OAP Data Evaluation Report - Sumary

26 Partictpating_aboratories

March_1984

Media. Nuclide Known Value Participants (a)

Media Nuclide Known Yalue Participants (a)

Control

Number Number

Outside Performing

Air

$0.312 E+04$

$0.326 \mathrm{E}+04$

$0.319 \mathrm{E}+04$

CR5 I

$0.313 \mathrm{E}+04$

$\mathrm{CO60}$

$0.343 E+03$

$0.359 \mathrm{E}+03$

$936 \mathrm{E}+03$

$.939 E+03$

$.103 \mathrm{E}+03$

Limits Analysis

SR90 $\quad 0.244 \mathrm{E}+01$

$0.288 \mathrm{E}+01$

CS137

$0.393 E+03$

$0.395 E+03$

$.732 \mathrm{E}+00$

PU239

$0.212 \mathrm{E}+01$

$0.182 \mathrm{E}+01$

$.118 \mathrm{E}+03$

$.054 E+00$

13

13

14

AM241 $0.169 \mathrm{E}+01$

$0.152 \mathrm{E}+01$

$0.761 E+00$

$0.235 \mathrm{E}+01$

U234

$0.209 \mathrm{E}+01$

$0.220 \mathrm{E}+01$

$0.627 \mathrm{E}+00$

$0.636 \mathrm{E}+00$

5

14

13

UPCI $\quad 0.421 \mathrm{E}+01$

$0.421 E+01$

$0.189 \mathrm{E}+01$

$0.573 \mathrm{E}+01$

$0.270 \mathrm{E}+01$

$0.713 E+02$

$0.208 \mathrm{E}+02$

$0.426 \mathrm{E}+02$

$0.127 \mathrm{E}+02$

$0.138 \mathrm{E}+01$

4

2

2

Water

CR51

$0.694 \mathrm{E}+02$

$0.477 \mathrm{E}+01$

$0.134 \mathrm{E}+01$

$0.456 E+01$

$0.660 \mathrm{E}-01$

$0.243 \mathrm{E}+00$

$0.164 \mathrm{E}+01$

1

CO60

$0.447 E+01$

CS137

$0.546+01$

$0.552 E+0 I$

$0.675 \mathrm{E}-03$

$0.118 \mathrm{E}-01$

$0.117 \mathrm{E}-01$

$0.660 \mathrm{E}-02$

$0.183 \mathrm{E}-02$

$.590 \mathrm{E}-02$

$0.180 \mathrm{E}-02$

$0.190 \mathrm{E}-01$

$0.545 \mathrm{E}-02$

$0.787 \mathrm{E}-02$

19

19

18

UPCI

$0.600 \mathrm{E}-02$

$0.197 \mathrm{E}-01$

$0.175 \mathrm{E}-01$

$0.946 \mathrm{E}+01$

$0.378 \mathrm{E}+01$

$0.246 \mathrm{E}+01$

$0.774 \mathrm{E}+00$

$0.126 \mathrm{E}+01$

$0.300 \mathrm{E}+00$

19

8

19

SR90 $\quad 0.258 \mathrm{E}+01$

CS137

$0.100+01$

$0.853 E+00$

$0.297 \mathrm{E}+00$

$0.420 \mathrm{E}-01$

$0.180 \mathrm{E}-0 \mathrm{l}$

$0.495 \mathrm{E}-02$

15

6

RA226
PU238

$0.660 \mathrm{E}+00$

$0.173 \mathrm{E}-01$

$0.270 \mathrm{E}-02$

$0.720 \mathrm{E}-02$

$0.222 E+00$

$0.735 \mathrm{E}+00$

$0.243 \mathrm{E}+00$

$0.810 E+00$

$0.667 E+00$ 
IABLE 3. AAP Data Evaluation Report - Summary (Continued)

\begin{tabular}{|c|c|c|c|c|c|c|}
\hline Media & Nuclide & $\begin{array}{c}\text { EML } \\
\text { Known Yalue }\end{array}$ & $\begin{array}{c}\text { Mean of } \\
\text { Participants }(a)\end{array}$ & $\begin{array}{l}\text { Contrq? } \\
\text { Linits }\end{array}$ & $\begin{array}{l}\text { Number } \\
\text { Outside } \\
\text { Limits }\end{array}$ & $\begin{array}{l}\text { Number } \\
\text { Performing } \\
\text { Analysis. }\end{array}$ \\
\hline Soil & UUG & $0.225 E+01$ & $0.184 \mathrm{E}+01$ & $0.101 E+01$ & 3 & 9 \\
\hline Tissue & $\begin{array}{l}\text { SR90 } \\
\text { CS137 } \\
\text { PL238 }\end{array}$ & $\begin{array}{l}0.444 \mathrm{E}+01 \\
0.178 \mathrm{E}+01 \\
0.740 \mathrm{E}-01\end{array}$ & $\begin{array}{l}0.558 \mathrm{E}+01 \\
0.191 \mathrm{E}+01 \\
0.740 \mathrm{E}-01\end{array}$ & $\begin{array}{l}0.133 E+01 \\
0.534 E+00 \\
0.333 E-01\end{array}$ & $\begin{array}{l}0 \\
3 \\
0\end{array}$ & $\begin{array}{r}4 \\
12 \\
9\end{array}$ \\
\hline & $\begin{array}{l}\text { PU239 } \\
\text { AM241 }\end{array}$ & $\begin{array}{l}0.190 \mathrm{E}-01 \\
0.140 \mathrm{E}-01\end{array}$ & $\begin{array}{l}0.238 \mathrm{E}-01 \\
0.198 \mathrm{E}-01\end{array}$ & $\begin{array}{l}0.855 \mathrm{E}-02 \\
0.630 \mathrm{E}-02\end{array}$ & $\begin{array}{l}2 \\
1\end{array}$ & $\begin{array}{r}10 \\
4\end{array}$ \\
\hline Vegetn & $\begin{array}{l}\text { K40 } \\
\text { SR90 } \\
\text { CS137 }\end{array}$ & $\begin{array}{l}0.139 \mathrm{E}+02 \\
0.356 \mathrm{E}+01 \\
0.138 \mathrm{E}+01\end{array}$ & $\begin{array}{l}0.760 \mathrm{E}+01 \\
0.358 \mathrm{E}+01 \\
0.146 \mathrm{E}+01\end{array}$ & $\begin{array}{l}0.417 \mathrm{E}+01 \\
0.107 \mathrm{E}+01 \\
0.414 \mathrm{E}+00\end{array}$ & $\begin{array}{l}6 \\
0 \\
3\end{array}$ & $\begin{array}{r}9 \\
5 \\
12\end{array}$ \\
\hline & $\begin{array}{l}\text { RA226 } \\
\text { PU238 } \\
\text { PU239 }\end{array}$ & $\begin{array}{l}0.110 \mathrm{E}-01 \\
0.650 \mathrm{E}-01 \\
0.160 \mathrm{E}-01\end{array}$ & $\begin{array}{c}- \\
0.600 E-01 \\
0.178 E-01\end{array}$ & $\begin{array}{l}0.495 \mathrm{E}-02 \\
0.293 \mathrm{E}-01 \\
0.720 \mathrm{E}-02\end{array}$ & $\begin{array}{l}3 \\
0 \\
2\end{array}$ & $\begin{array}{r}3 \\
10 \\
10\end{array}$ \\
\hline & $\begin{array}{l}\text { AM241 } \\
\text { U23 } 4 \\
\text { U238 }\end{array}$ & $\begin{array}{l}0.113 \mathrm{E}-01 \\
0.140 \mathrm{E}-01 \\
0.130 \mathrm{E}-01\end{array}$ & $\begin{array}{l}0.143 E-01 \\
0.700 E-02 \\
0.100 E-01\end{array}$ & $\begin{array}{l}0.508 \mathrm{E}-02 \\
0.420 \mathrm{E}-02 \\
0.390 \mathrm{E}-02\end{array}$ & $\begin{array}{l}1 \\
2 \\
0\end{array}$ & $\begin{array}{l}3 \\
2 \\
2\end{array}$ \\
\hline & $\begin{array}{l}\text { UPCI } \\
\text { UUG }\end{array}$ & $\begin{array}{l}0.270 \mathrm{E}-01 \\
0.390 \mathrm{E}-01\end{array}$ & $0 . \overline{191 \mathrm{E}-01}$ & $\begin{array}{l}0.122 \mathrm{E}-01 \\
0.176 \mathrm{E}-01\end{array}$ & $\frac{1}{4}$ & $\begin{array}{l}1 \\
6\end{array}$ \\
\hline
\end{tabular}

(a) All values included except extreme outliers.

(b) Control limits for single analysts. For replicate analysis Timits, see Table 1 . 
TABLE 4. QAP Data Evaluation Report - Laboratory Performance Summary LABORATORIES

NUCLIDES N BA BE BN BP BZ CS EN EN GA KA LA LL LIL NL OR PA PI PR RE RE SA SR UC UK UY

Air

BE7

CR51
CO60

SR90

CS137

PU239

AM241

U234

U238

UPCI

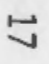

UUG

Hater

H3

CR51

MN54

C060

SR90

CS137

PU239

AM241

U23 4

U238

UPCI

UUG

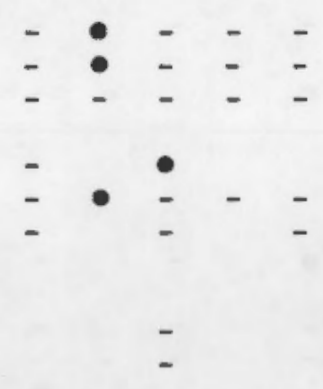


TABLE 4. QAP Data Evaluation Report - Laboratory Performance Summary (Continued)

LABCRATORIES

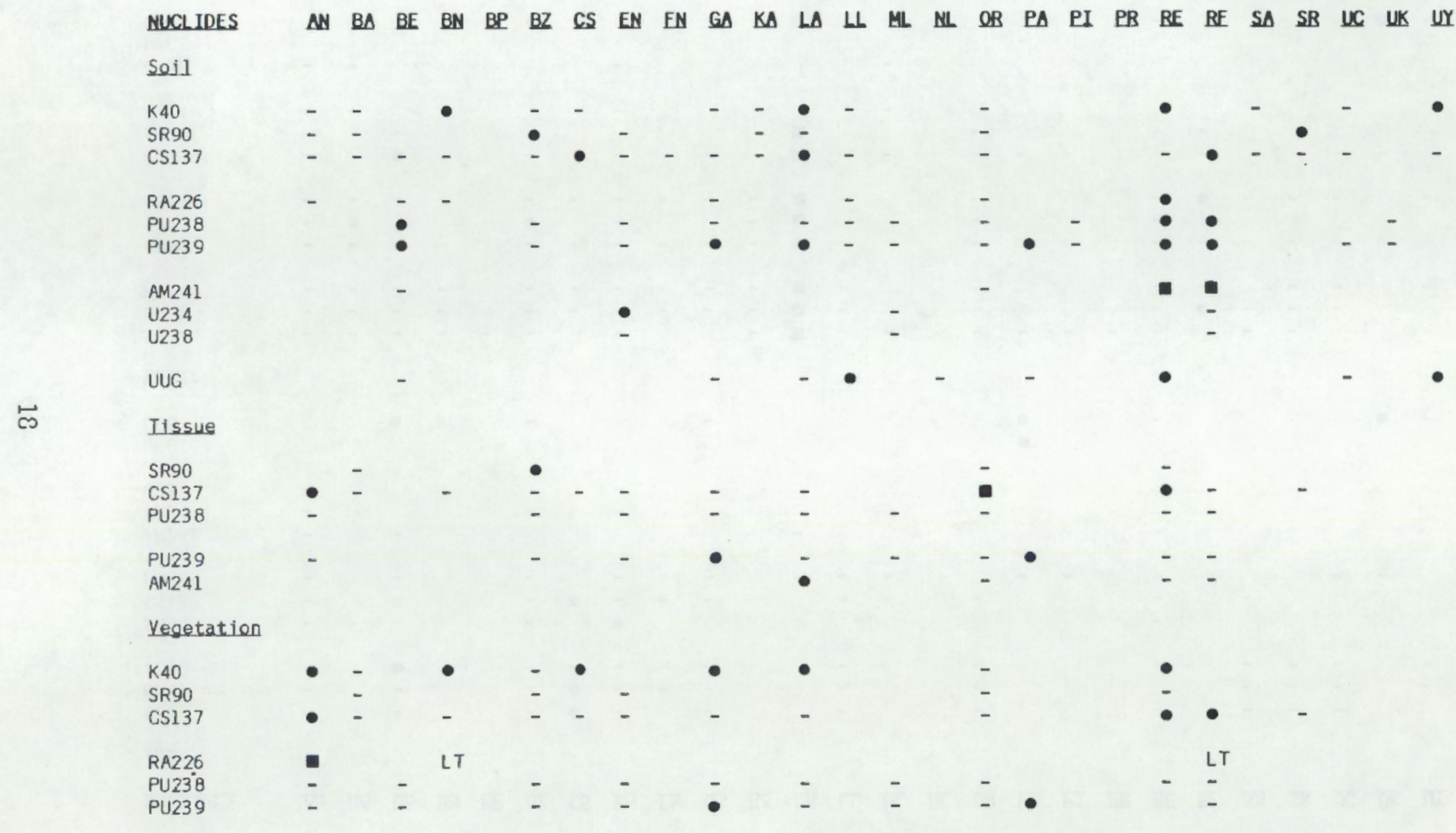


TABLE 4. QAP Data Evaluation Report - Laboratory Performance Summary (Continued)

LABARATORIES

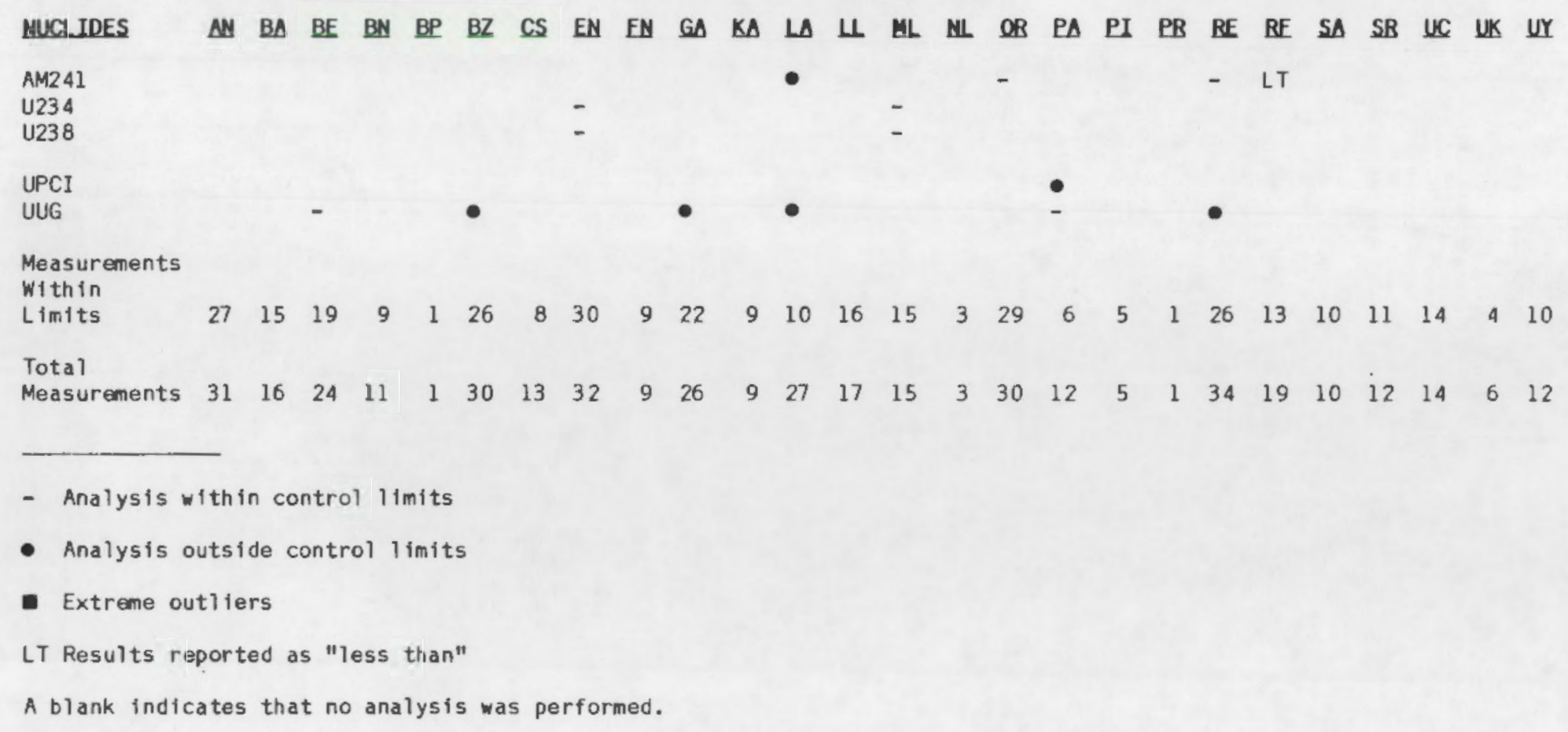

- Analysis within control limits

- Analysis outside control limits

- Extreme outliers

LT Results reported as "less than"

A blank indicates that no analysis was performed. 
A 
IABLE 5. Sumary of Analysis of Gana Enitters in A1r Filters and Water Samples

\begin{tabular}{|c|c|c|c|c|c|c|}
\hline Madia & Nuclide & $\begin{array}{l}\text { Number } \\
\text { Analyzing }\end{array}$ & Knoin & $\operatorname{Mean}(a)$ & $\frac{\text { Variation }}{\mathrm{x}}$ & Stdd Dey ${ }^{(a)}$ \\
\hline \multirow[t]{2}{*}{ Atr } & $\begin{array}{l}\text { BE7 } \\
\text { CR51 } \\
\text { CO60 }\end{array}$ & $\begin{array}{l}13 \\
13 \\
14\end{array}$ & $\begin{array}{r}3120 \\
3130 \\
343\end{array}$ & $\begin{array}{r}3258 \\
3190 \\
359\end{array}$ & $\begin{array}{l}+4.4 \\
+1.9 \\
+4.7\end{array}$ & $\begin{array}{r}448 \\
473 \\
47\end{array}$ \\
\hline & $\operatorname{CS} 137$ & 14 & 393 & 395 & +0.5 & 49 \\
\hline Water & $\begin{array}{l}\text { CR51 } \\
\text { MN54 } \\
\text { CO60 }\end{array}$ & $\begin{array}{l}19 \\
18 \\
19\end{array}$ & $\begin{array}{r}42.3 \\
4.59 \\
4.47\end{array}$ & $\begin{array}{r}42.6 \\
4.77 \\
4.56\end{array}$ & $\begin{array}{l}+0.7 \\
+3.9 \\
+2.0\end{array}$ & $\begin{array}{l}6.5 \\
0.43 \\
0.39\end{array}$ \\
\hline & $\operatorname{cs} 137$ & 19 & 5.46 & 5.52 & +1.1 & 0.68 \\
\hline
\end{tabular}

(a) All data included except extreme outliers. 


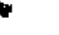


APPENDIX

BOX PLOTS, NORMAL PROBABILITY PLOTS AND STATISTICAL PARAMETERS
FOR GAMMA EMITTERS IN AIR FILTERS AND WATER (a)

(a) For plotting purposes, a 11 LA water data corrected by a factor of 1000 . 


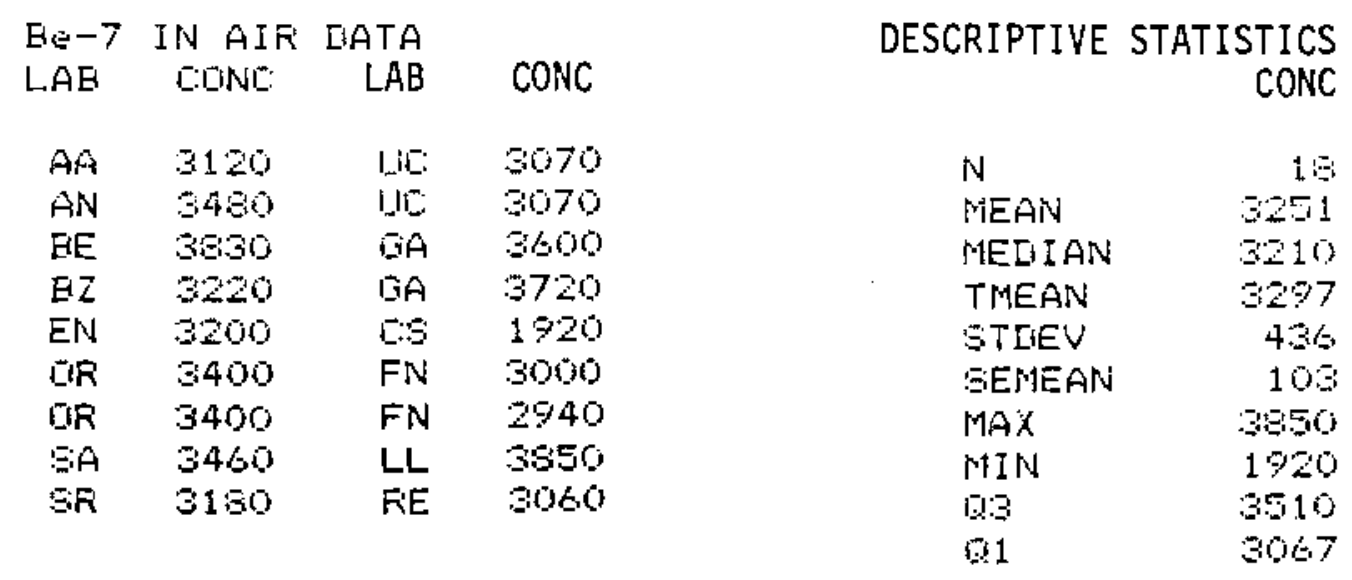

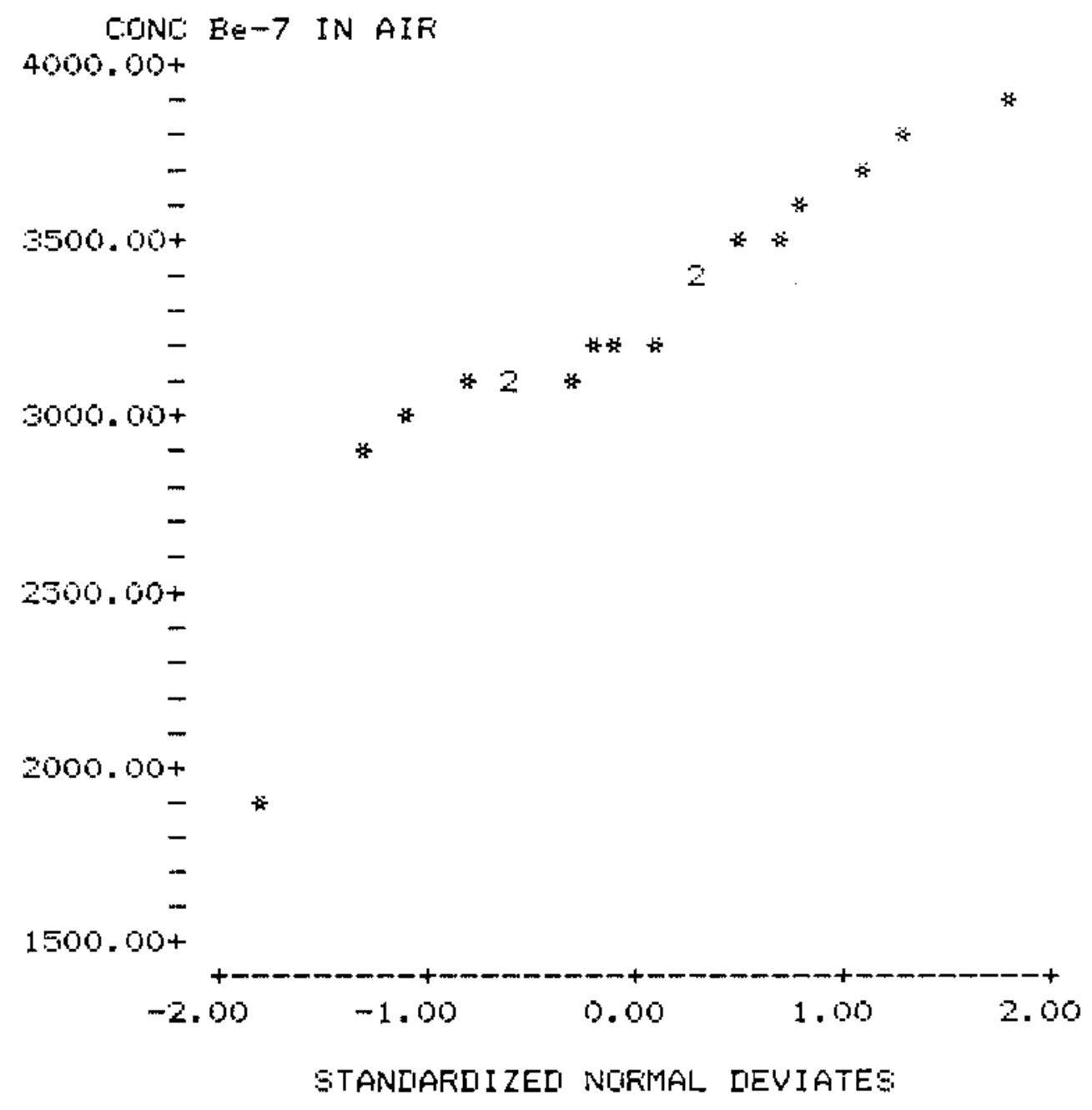

COKFELATION DF DONC AND NDRM. DEV= 0.921

A. 1 


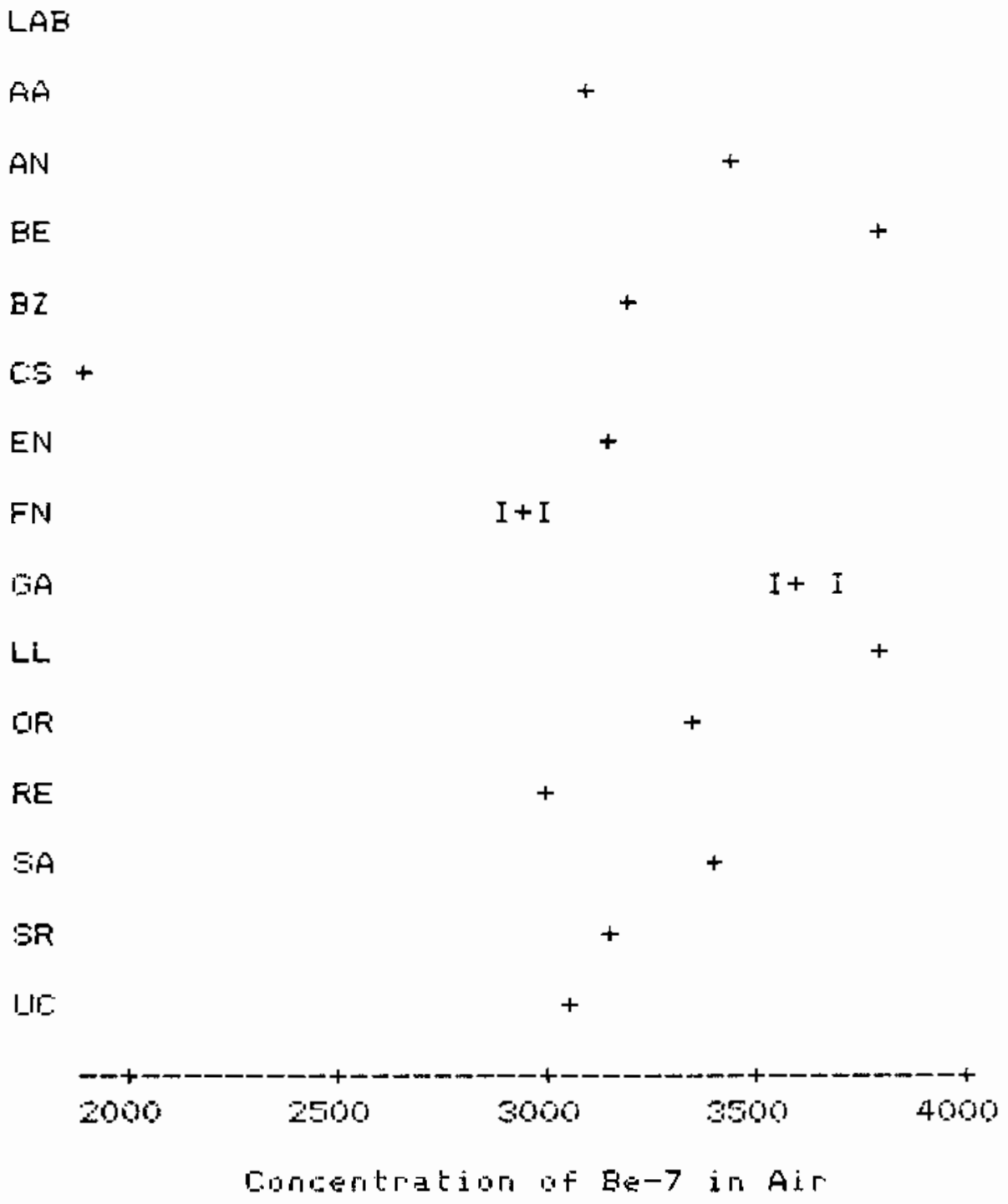

A. 2 


\begin{tabular}{|c|c|c|c|}
\hline $\begin{array}{l}C F-S I \\
L A F\end{array}$ & 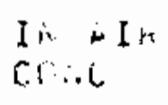 & $\begin{array}{l}\because A F A \\
\angle A B\end{array}$ & CONC \\
\hline$A A$ & 313.3 & L.C & 3340 \\
\hline$A \mathrm{~N}$ & S4: & UY & 316 \\
\hline $\mathrm{GE}$ & 2050 & $1, Y$ & 360 \\
\hline 62 & $3<<0$ & $\hat{G A}$ & 1 \\
\hline$E \wedge$ & 3360 & GA & $3 / 400$ \\
\hline UR & jous & $\mathrm{Cs}$ & 164 \\
\hline $\mathrm{OF}$ & 3200 & $F A$. & $2 r v$ \\
\hline$S A$ & 3350 & FR. & $20 a^{2}$ \\
\hline $5 F$ & 3140 & LL & 352 \\
\hline$v C$ & 3490 & & \\
\hline
\end{tabular}

DESCRIPTIVE STATISTICS
CONC

\begin{tabular}{|c|c|}
\hline$\sqrt{ }$ & $i *$ \\
\hline Y & $31: 3$ \\
\hline VEDI 1. & उEcu \\
\hline TNEA A & $j<-1$ \\
\hline STDEV & te \\
\hline SENEAR & 106 \\
\hline $\operatorname{MAX}$ & 3740 \\
\hline $\operatorname{MIN}$ & $10 ; 0$ \\
\hline $\begin{array}{l}23 \\
91\end{array}$ & 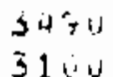 \\
\hline
\end{tabular}

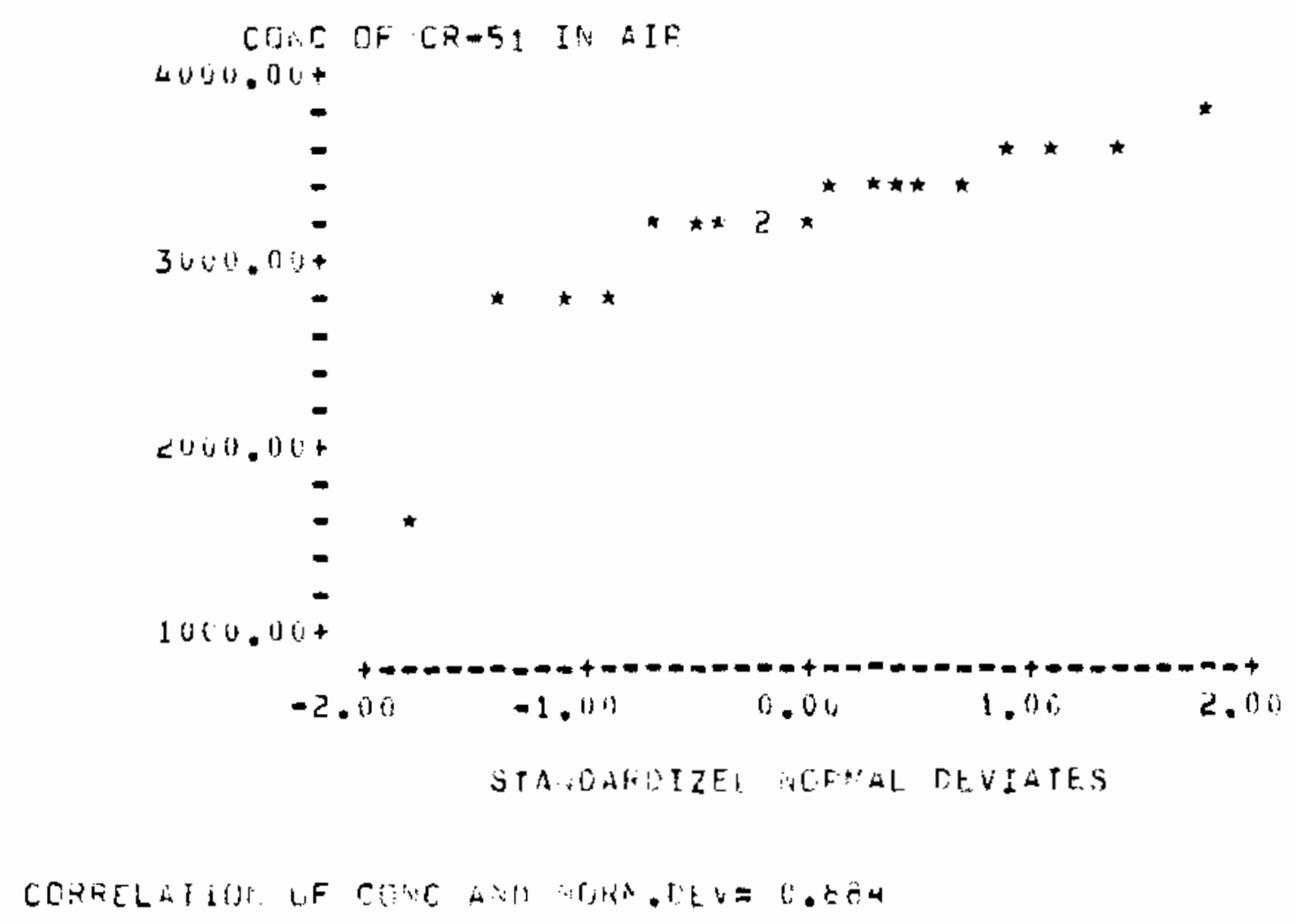

A. 3 
Lot

$A A+$

ii

$E_{i}$

$+$

$F$

G

LL

Din

5

$+$

5

IJ

$I+I$

UK

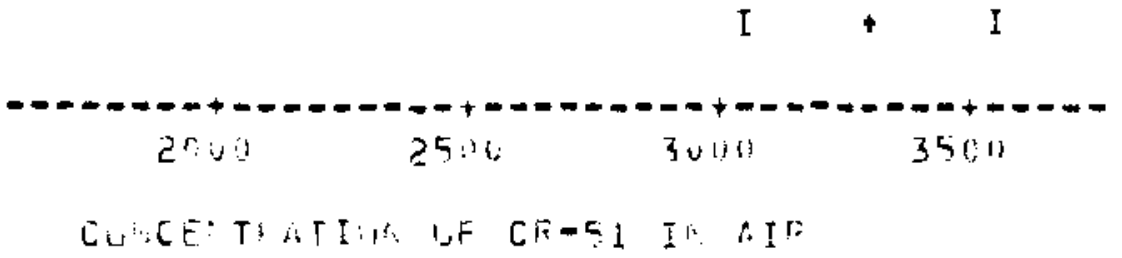

A. 4 


\begin{tabular}{|c|c|c|c|}
\hline $\begin{array}{l}C O=00 \\
\text { LAD }\end{array}$ & $\begin{array}{l}I=A r \\
C H 10\end{array}$ & $\begin{array}{l}\therefore 14 \\
\angle A B\end{array}$ & CONC \\
\hline$A \Delta$ & 343 & LC & 345 \\
\hline$A a^{\prime}$ & 305 & نy & 370 \\
\hline iot & 4n, & UY & 430 \\
\hline$\square \bar{L}$ & 374 & GA & Sob \\
\hline$E:$ & $30 \%$ & $G A$ & Sol \\
\hline $\mathrm{OH}$ & 336 & CS & $25 \%$ \\
\hline Gin & 340 & $F A$ & 331 \\
\hline SA & 317 & $F i$ & 335 \\
\hline SF & 334 & LL & 375 \\
\hline uc & 344 & $\mathrm{RE}$ & 385 \\
\hline
\end{tabular}

\section{DESCRIPTIVE STATISTICS \\ CONC}

MEAD $\quad 35 \%$

MEOIAI 3 T?

THEAN 35i.c

STOE

SEVEA: $\quad 1: 3$

MAX

III $\quad 25+0$

Q3 374.7

Q1 $33+.5$

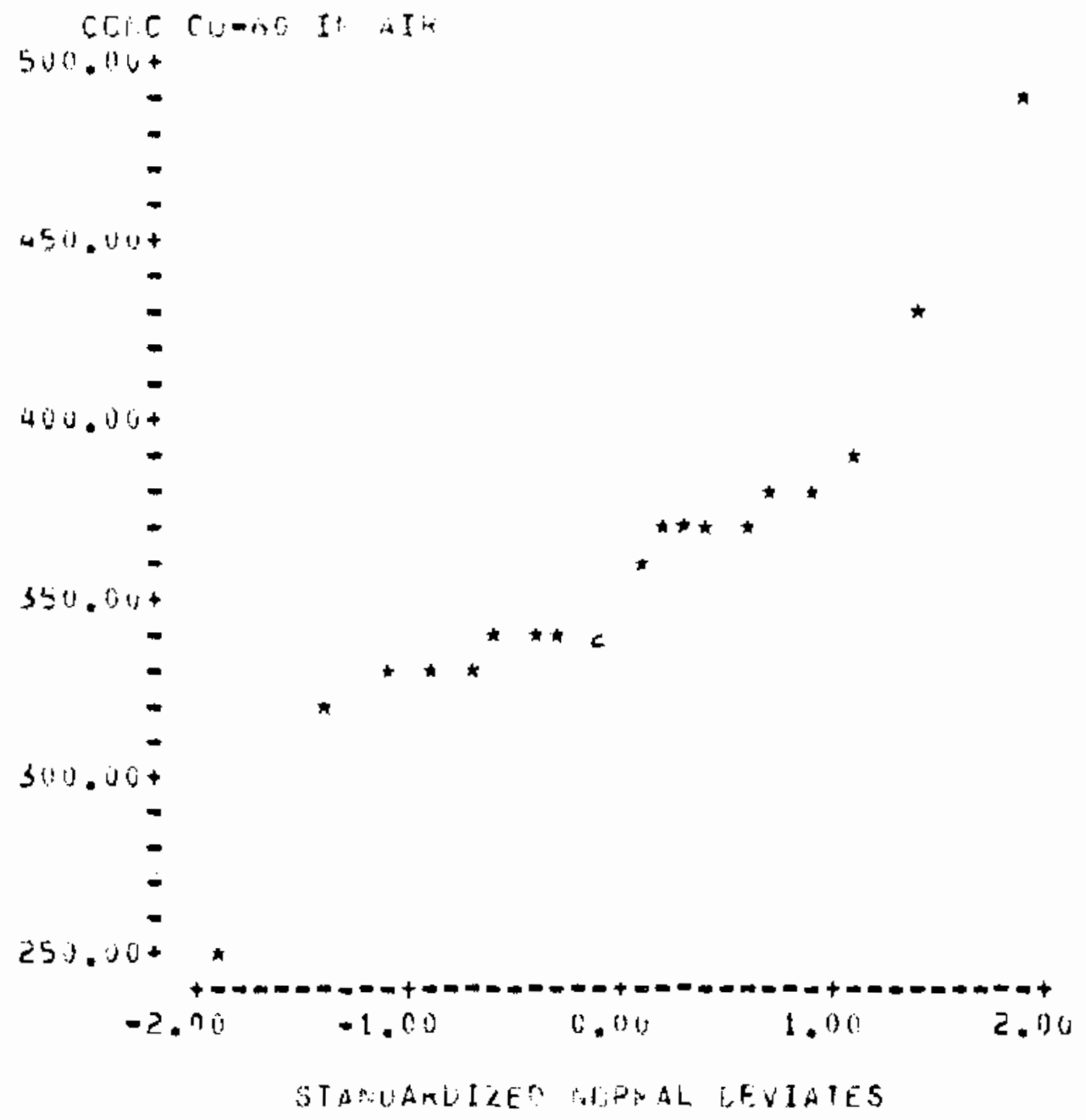

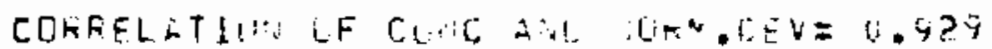


LAS

A4 +

Ai. $\quad+$

HE

R2 +

CS

Eis

$F:$

6) $\quad$ T+ I

L.L

DR $\quad I+I$

RE

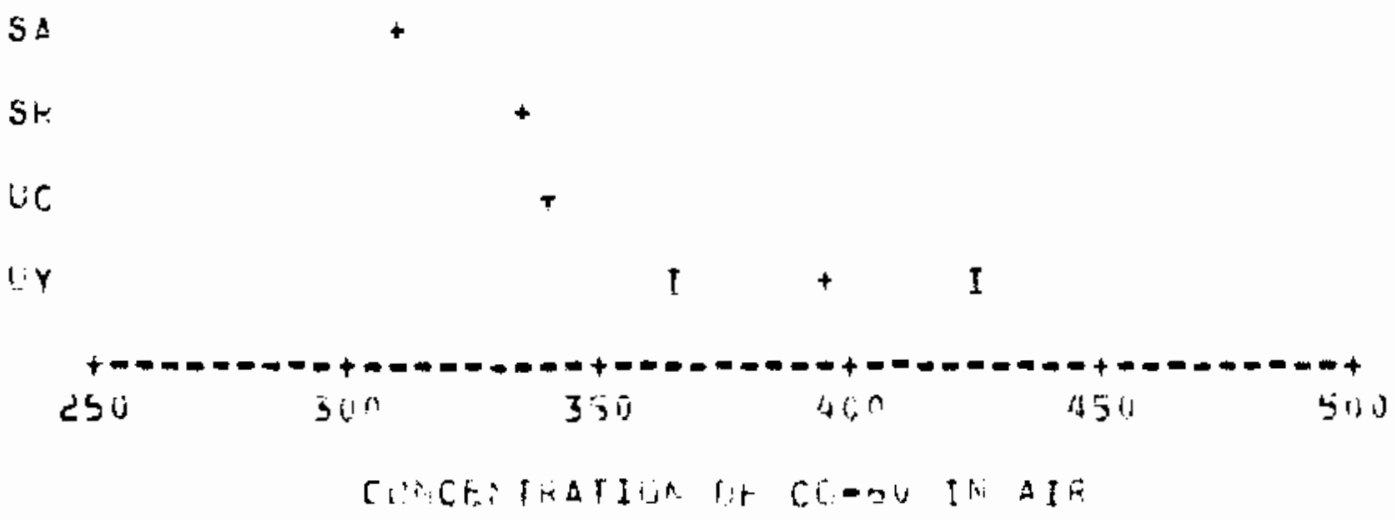

A. 6 


\begin{tabular}{|c|c|c|c|c|c|}
\hline $\begin{array}{l}C S=1 \\
L A E\end{array}$ & 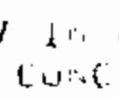 & $\begin{array}{l}1,4 \\
L A B\end{array}$ & CONC & DESCRIPT I VE & $\begin{array}{l}\text { STATISTIC } \\
\text { CONC }\end{array}$ \\
\hline AA & 395 & $1 \cdot \mathcal{C}$ & $3+1$ & $v$ & ¿." \\
\hline A. & $4 v 6$ & LY & 340 & MEDi. & $3+4.6$ \\
\hline I.E & 513 & $11 Y$ & 306 & MEIIAi. & $3 \div 5,3$ \\
\hline 82 & 392 & 64 & 350 & TANEAN & $3 \times 2.1$ \\
\hline$E^{h_{2}}$ & $4 \check{0}$ & GA & & STDEV & $1+7.4$ \\
\hline OR & 400 & $\tilde{\tau S}$ & coo & SENEAiv & 10.7 \\
\hline UR & 420 & $F i$ & 360 & $\max$ & 513.13 \\
\hline SA & 401 & $F \times$ & 30 & $M I N$ & cos. \\
\hline SF & 344 & LL & 471 & 23 & $41+\ldots$ \\
\hline$u C$ & 402 & RE & 410 & 1 & 571.0 \\
\hline
\end{tabular}

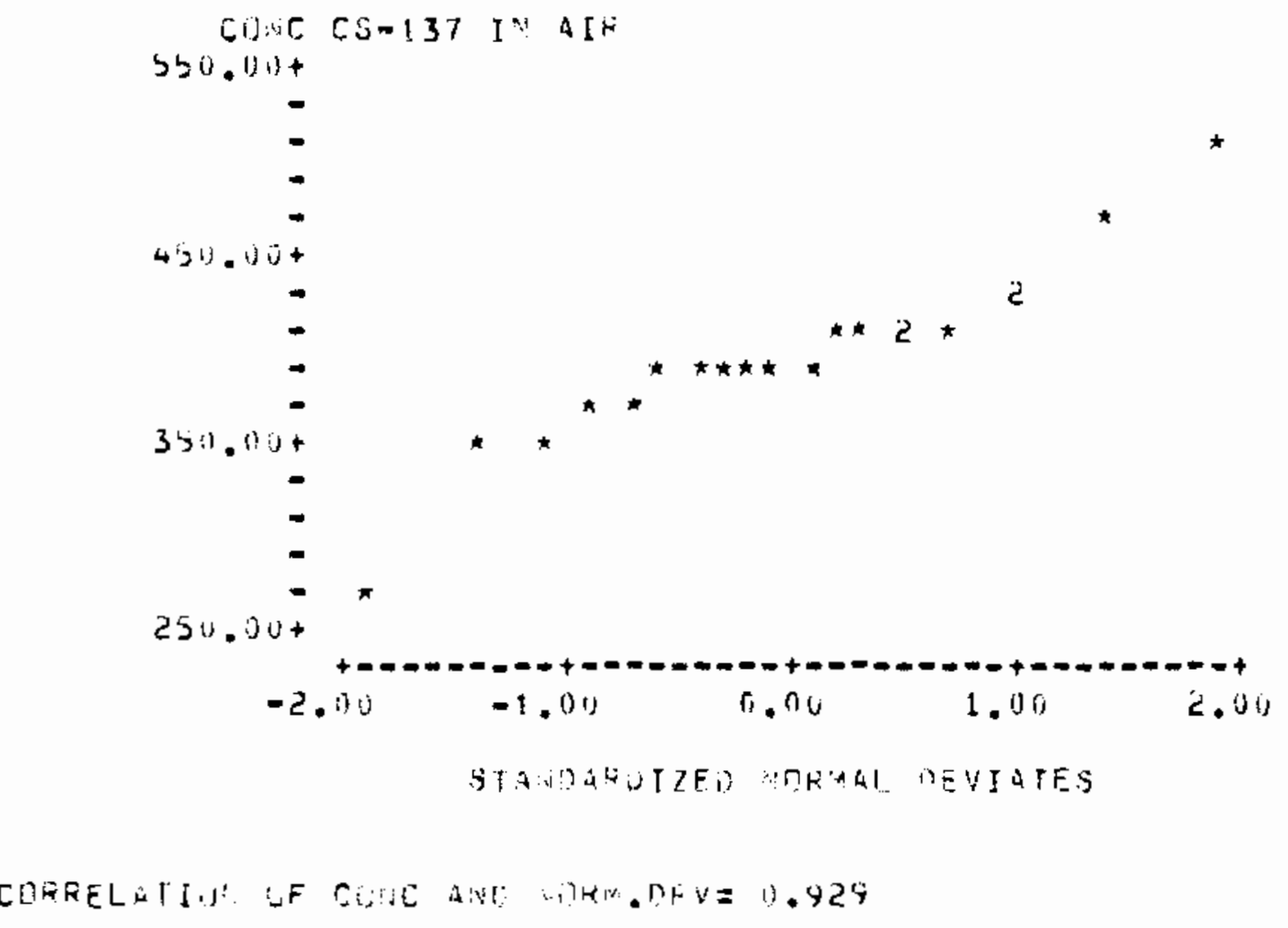


Lon

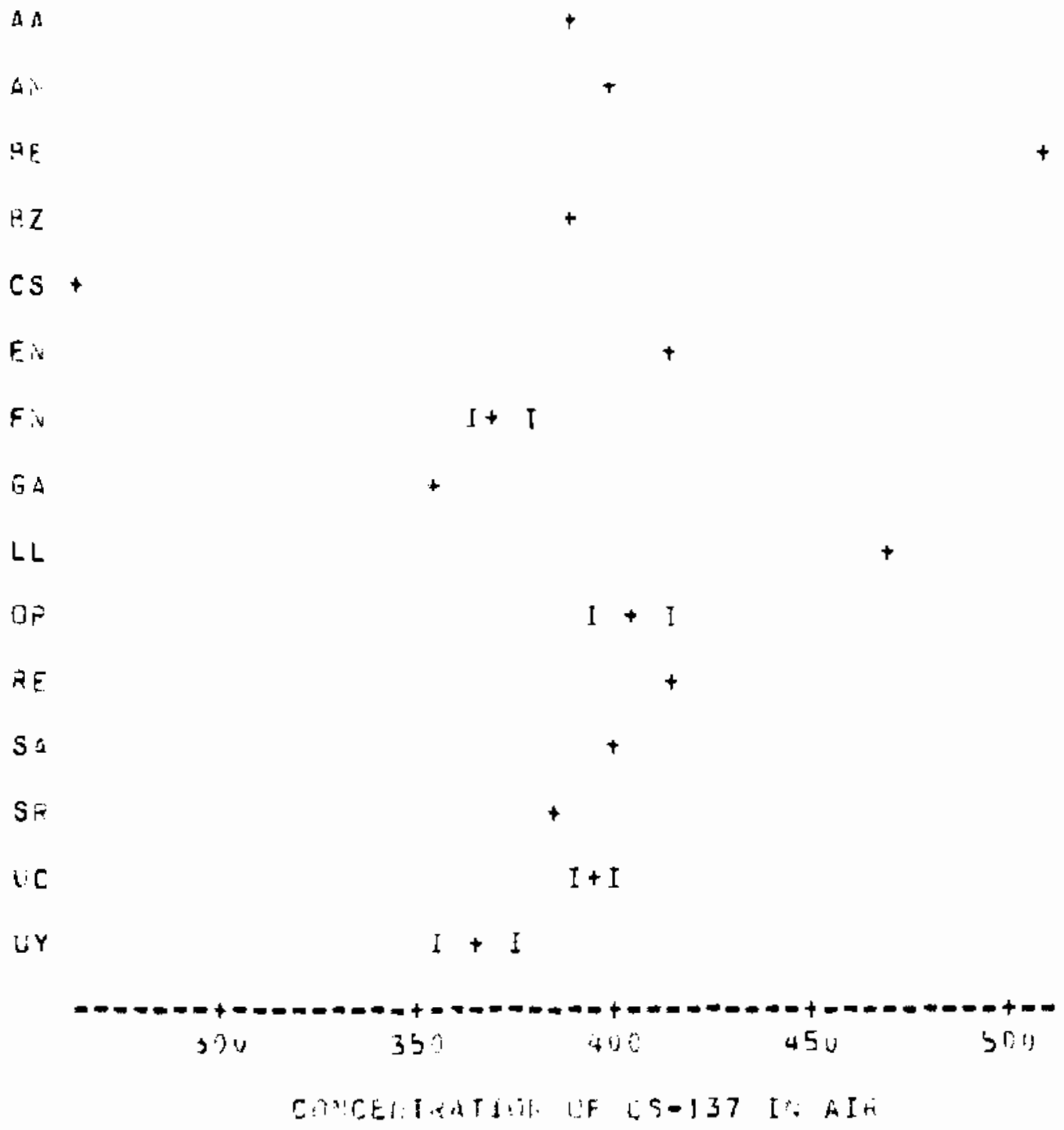

A. 8 


\begin{tabular}{|c|c|c|c|}
\hline $\begin{array}{l}\text { CH }-51 \\
\text { LAF }\end{array}$ & $\begin{array}{l}\operatorname{lin} \\
\mathrm{c} i: \bar{c}\end{array}$ & LAB & CONC \\
\hline$\Delta \Delta$ & $4 a c \cdot 3$ & SA & $4 \therefore: 1$ \\
\hline$A i_{2}$ & 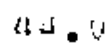 & $S t$ & 35.2 \\
\hline FA & 41.5 & UC & 41.6 \\
\hline $6 E$ & 46.6 & UY & 47.0 \\
\hline$B Z$ & $45 \cdot 2$ & GA & $40 .=$ \\
\hline$E N$ & 43.0 & is $N$ & 43.6 \\
\hline LA & 40.7 & CS & 43.2 \\
\hline LA & 48.1 & $F N_{i}$ & $5 \ddot{c} \cdot i$ \\
\hline LA & 41.0 & KA & 43. \\
\hline UR & 41.0 & LL & 44.8 \\
\hline RF & 22.0 & RE & 30.5 \\
\hline
\end{tabular}

DESCRIPTIVE STATISTICS

CONC

\begin{tabular}{|c|c|}
\hline $\mathrm{N}$ & $r 2$ \\
\hline MEAI: & 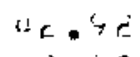 \\
\hline MEDIA:D & $43 .=0$ \\
\hline TA E A : & $+5 . \leq 1$ \\
\hline STDF. & +.2 \\
\hline $\begin{array}{l}\text { SENEAMA } \\
\text { MAX }\end{array}$ & $\begin{array}{r}1 . c \% \\
42.60\end{array}$ \\
\hline$M I N$ & $c<, 1, b$ \\
\hline $\begin{array}{l}03 \\
01\end{array}$ & $\begin{array}{l}+c .25 \\
+1.0 u\end{array}$ \\
\hline
\end{tabular}

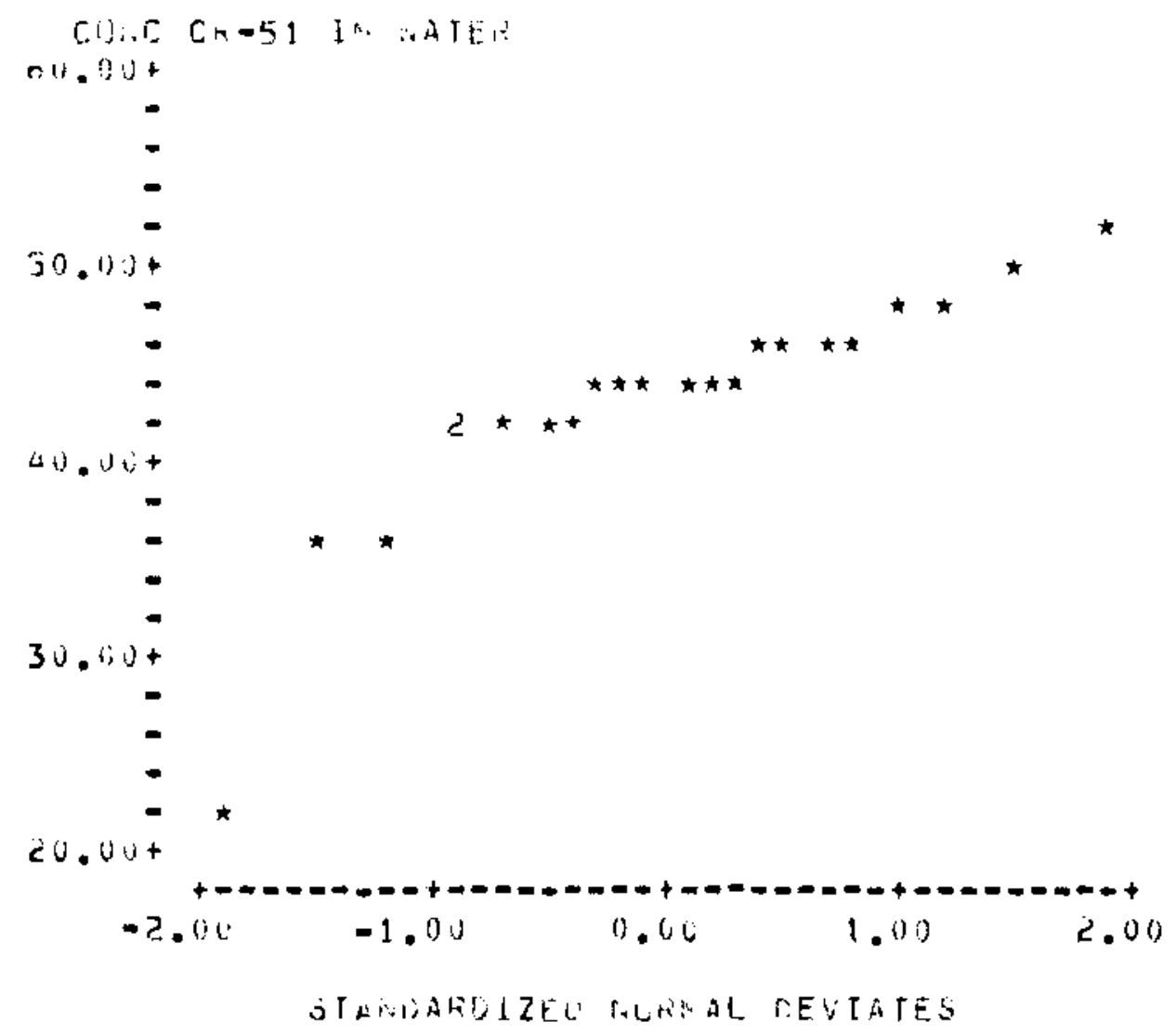

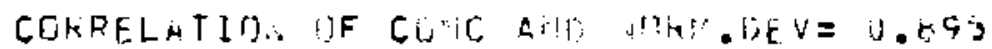




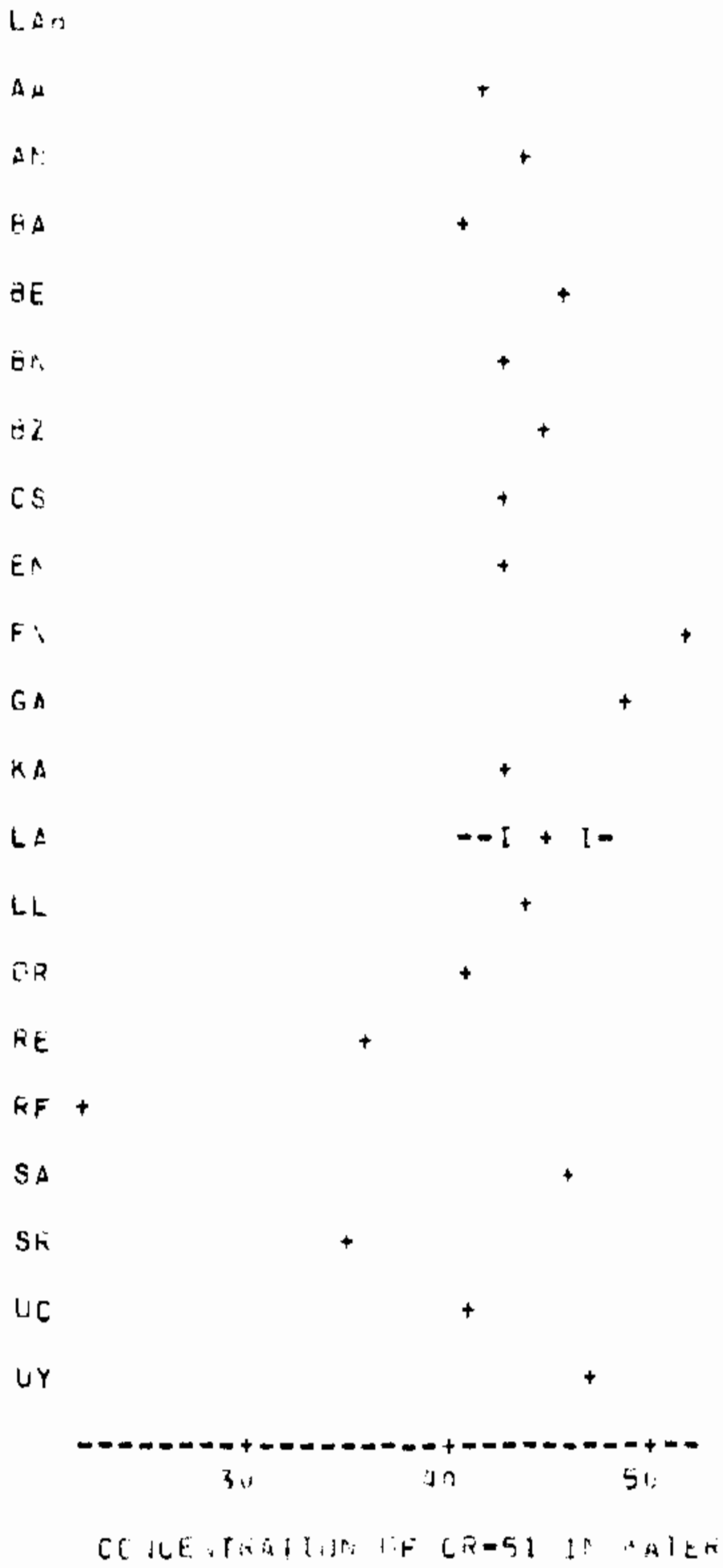

A. 10 


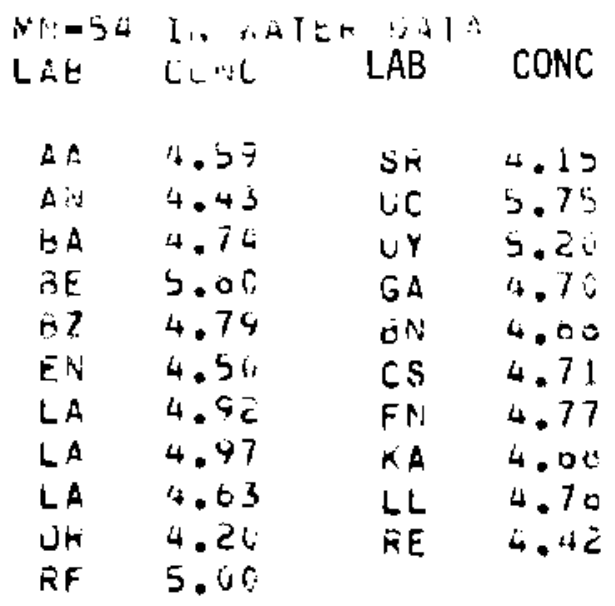

\section{DESCRIPTIVE STATISTICS}

CONC

\begin{tabular}{|c|c|}
\hline$\hat{N}$ & :1 \\
\hline MEA & $4.7,11$ \\
\hline VEDI $A^{*}$ & 4.710 \\
\hline TMEAN & 4.751 \\
\hline STOEV & $0.3+1$ \\
\hline SEFEA & ט. \\
\hline$A A x$ & 3.154 \\
\hline $4 I N$ & 4.150 \\
\hline 03 & \\
\hline 1 & 5.5. \\
\hline
\end{tabular}

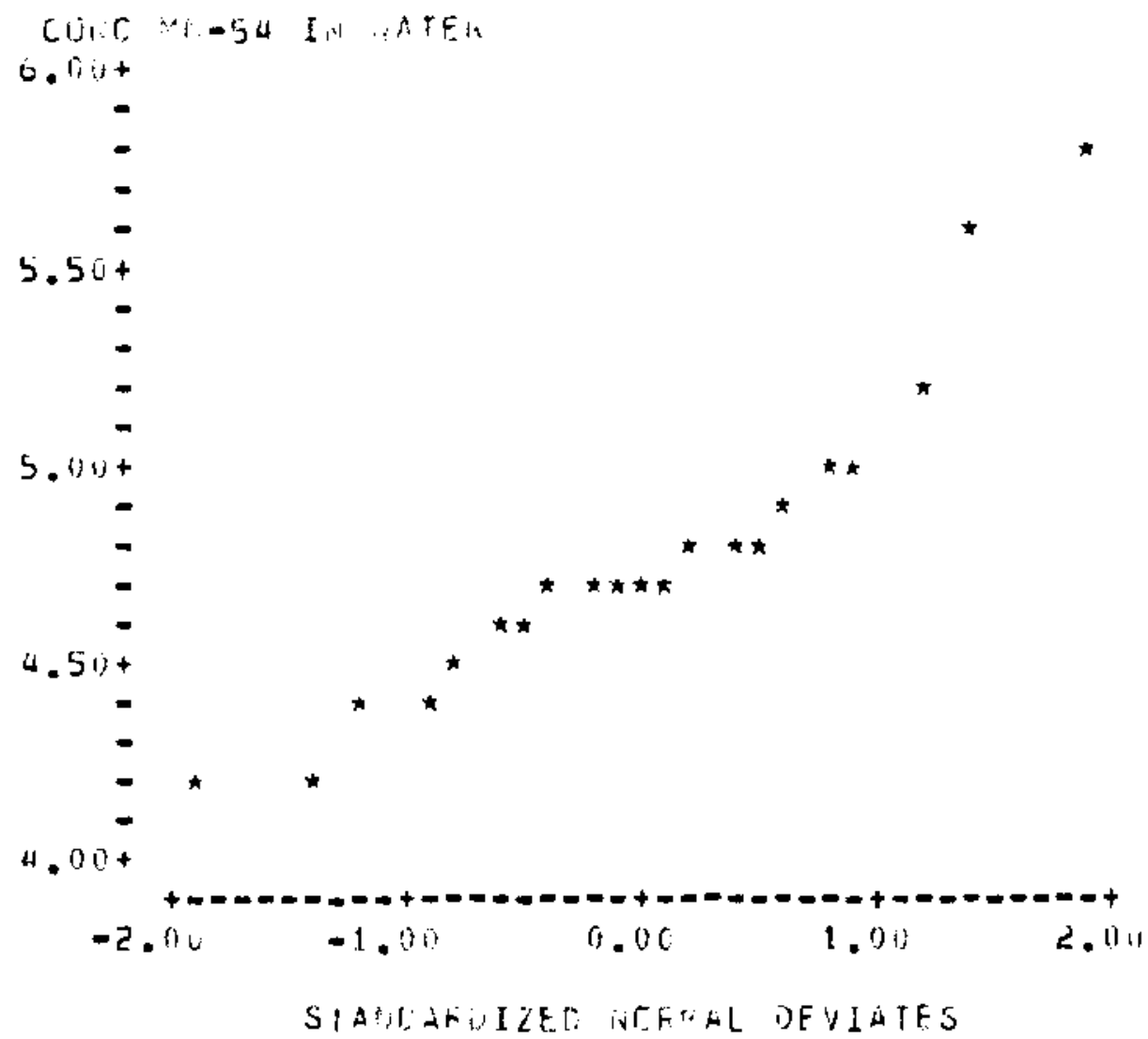

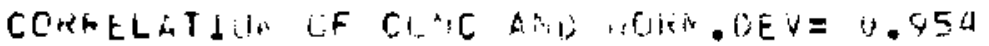




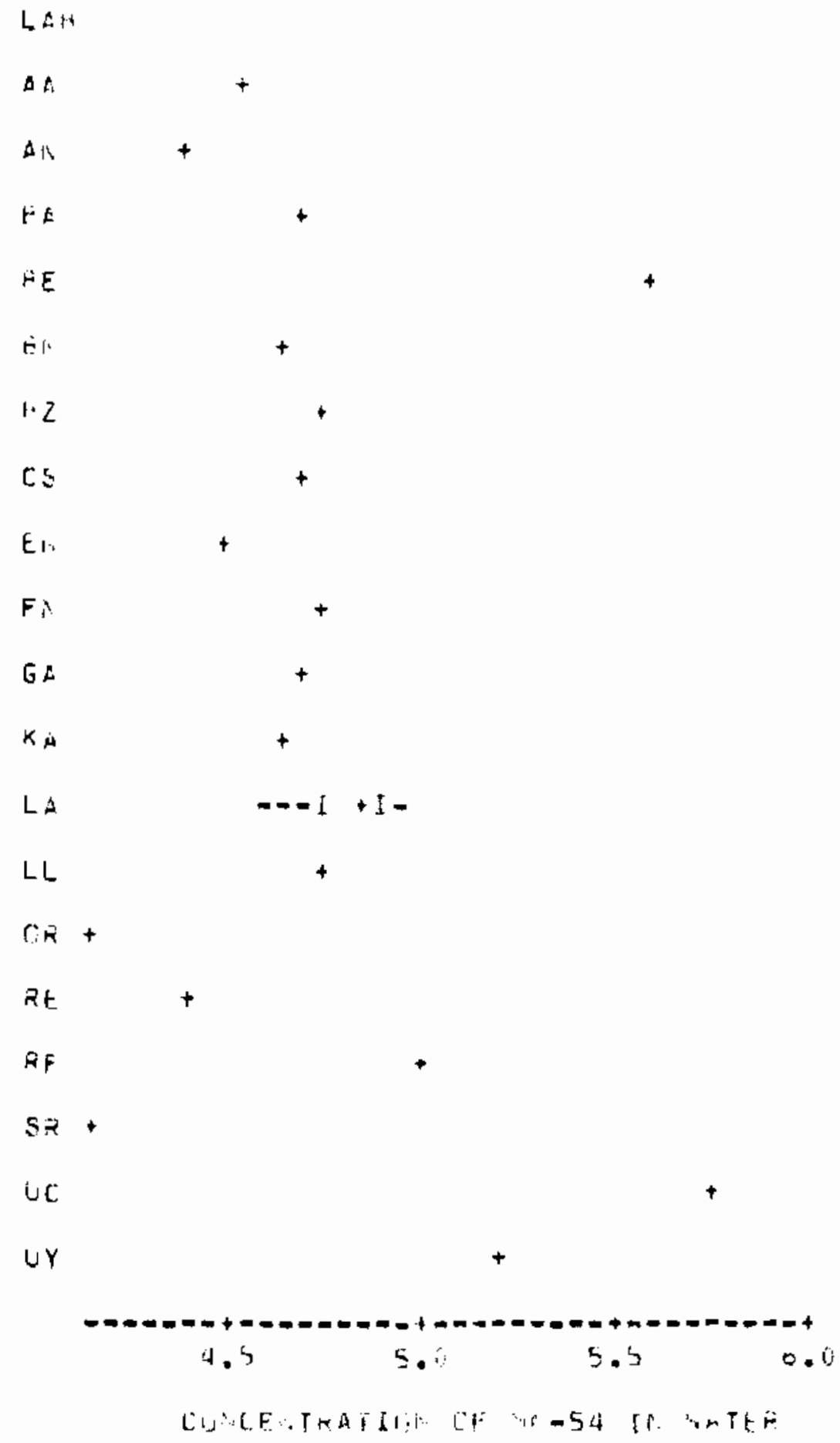

A. 12 


\begin{tabular}{|c|c|c|c|c|c|}
\hline $\begin{array}{l}C 1-60 \\
\operatorname{LAB}\end{array}$ & 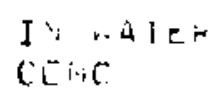 & $\begin{array}{l}b A B \\
L A B\end{array}$ & CONC & DESCRIPTIVE & $\begin{array}{c}\text { STATISTIC } \\
\text { CONC }\end{array}$ \\
\hline$A A$ & 11.47 & SA & $4.7 \mathrm{C}$ & iv & $c<$ \\
\hline$A N$ & 4.06 & $3 \vec{F}$ & 4.25 & MEA & 4.545 \\
\hline$B A$ & 4.59 & $\cup C$ & $\therefore .4$ & $M E[I \Delta$, & 4.465 \\
\hline af & 5.04 & LY & 4.40 & TMEAN & t. .10 \\
\hline$B Z$ & 4.55 & GA & 4.50 & STOEV & 0,352 \\
\hline E Piv & 4.40 & $B A:$ & 4.56 & SEMEA V & 6.075 \\
\hline LA & 4.63 & $C S$ & 4.56 & $\sin x$ & 5.01iv \\
\hline LA & 4.48 & $F A:$ & 4.43 & $M I N !$ & 4.0ui \\
\hline LA & 4.30 & RA & 4.32 & $1 / 3$ & $4 . n \cdot 8$ \\
\hline$D R$ & 4.00 & LL & 4.40 & 01 & 4.587 \\
\hline RF & 5.00 & $R E$ & 4.22 & & \\
\hline
\end{tabular}

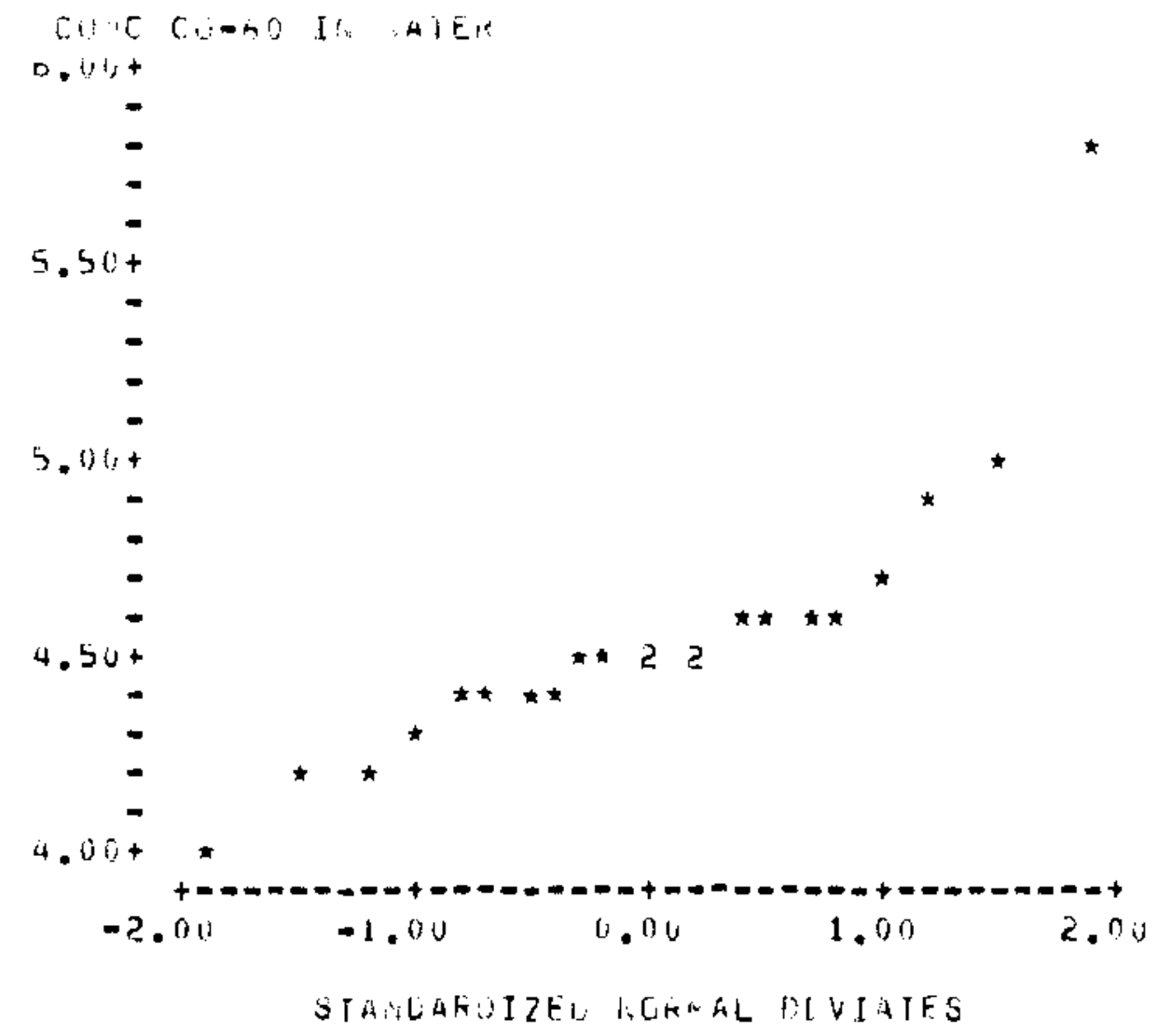

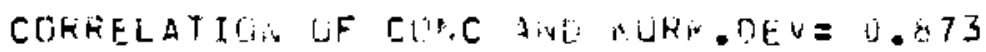




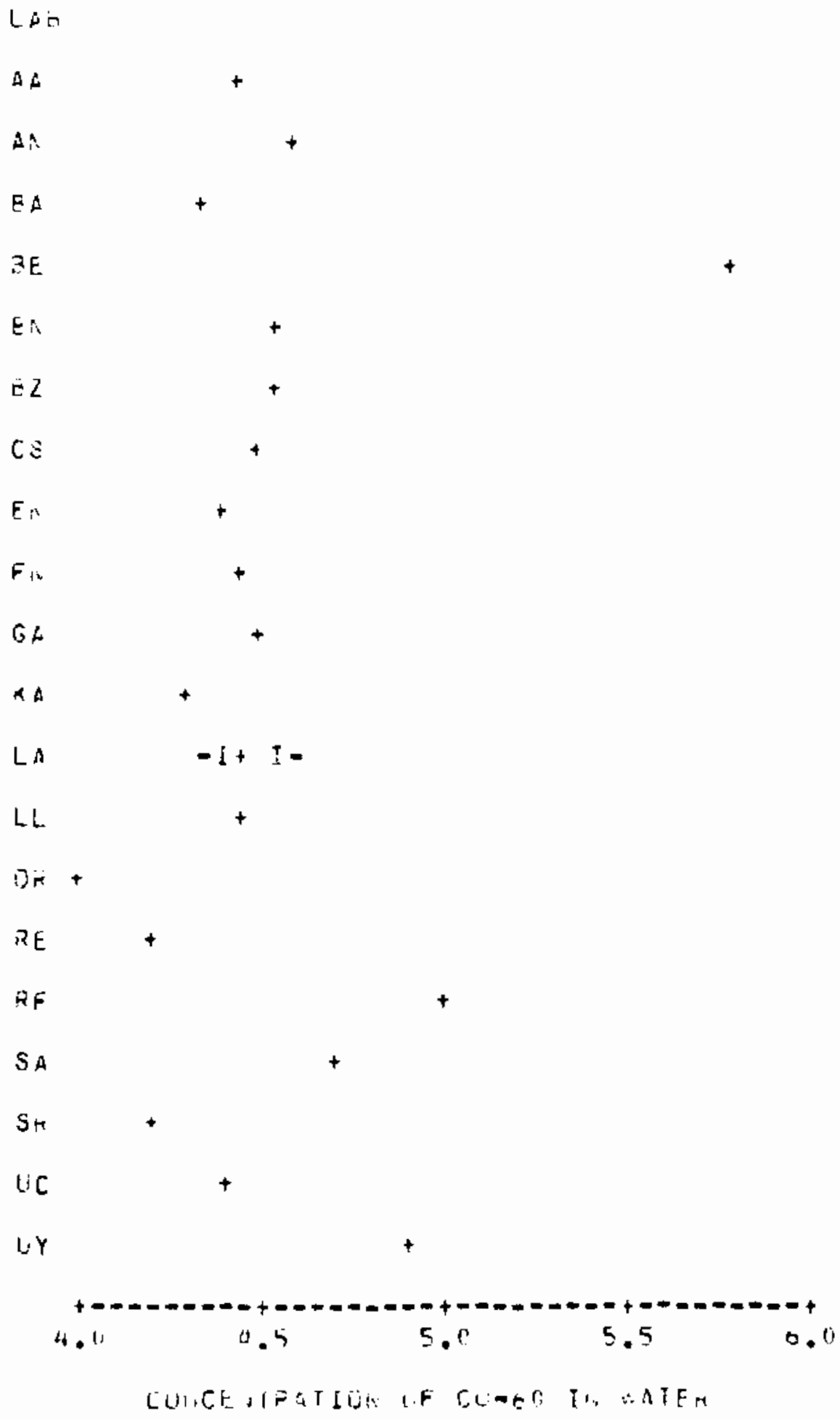

A. 14 


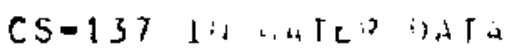

LAE C. IL LAB CONC

$\begin{array}{llll}\text { AA } & 5.40 & \text { SA } & 5.40 \\ \text { AA } & 5.40 & \text { SH } & 4.45 \\ \text { EA } & 5.47 & \text { UC } & 0.10 \\ \text { OE } & 5.50 & \text { UY } & 7.01 \\ \text { OL } & 5.04 & G A & 5.25 \\ \text { EN } & 5.40 & \text { EN } & 5.51 \\ \text { LA } & 5.97 & \text { CS } & 5.00 \\ \text { LA } & 5.94 & \text { FN } & 5.55 \\ \text { LA } & 5.64 & \text { IA } & 5.70 \\ \text { OR } & 5.00 & \text { LL } & 5.71 \\ \text { HF } & 3.50 & \text { RE } & 5.31\end{array}$

DESCRIPTIVE STATISTICS

CONC

\begin{tabular}{|c|c|}
\hline v & $\dot{r}$. \\
\hline MEA: & 5.3 .2 \\
\hline$\triangle A E D I A:$. & 2.355 \\
\hline T:AE A & 5.064 \\
\hline SIDEV & u. .3. \\
\hline SENEAIV & 1.134 \\
\hline $\operatorname{MAx}$ & 0.700 \\
\hline$M I N$ & 3.5 .04 \\
\hline 103 & 5.970 \\
\hline 1 & $5.3 \% 2$ \\
\hline
\end{tabular}

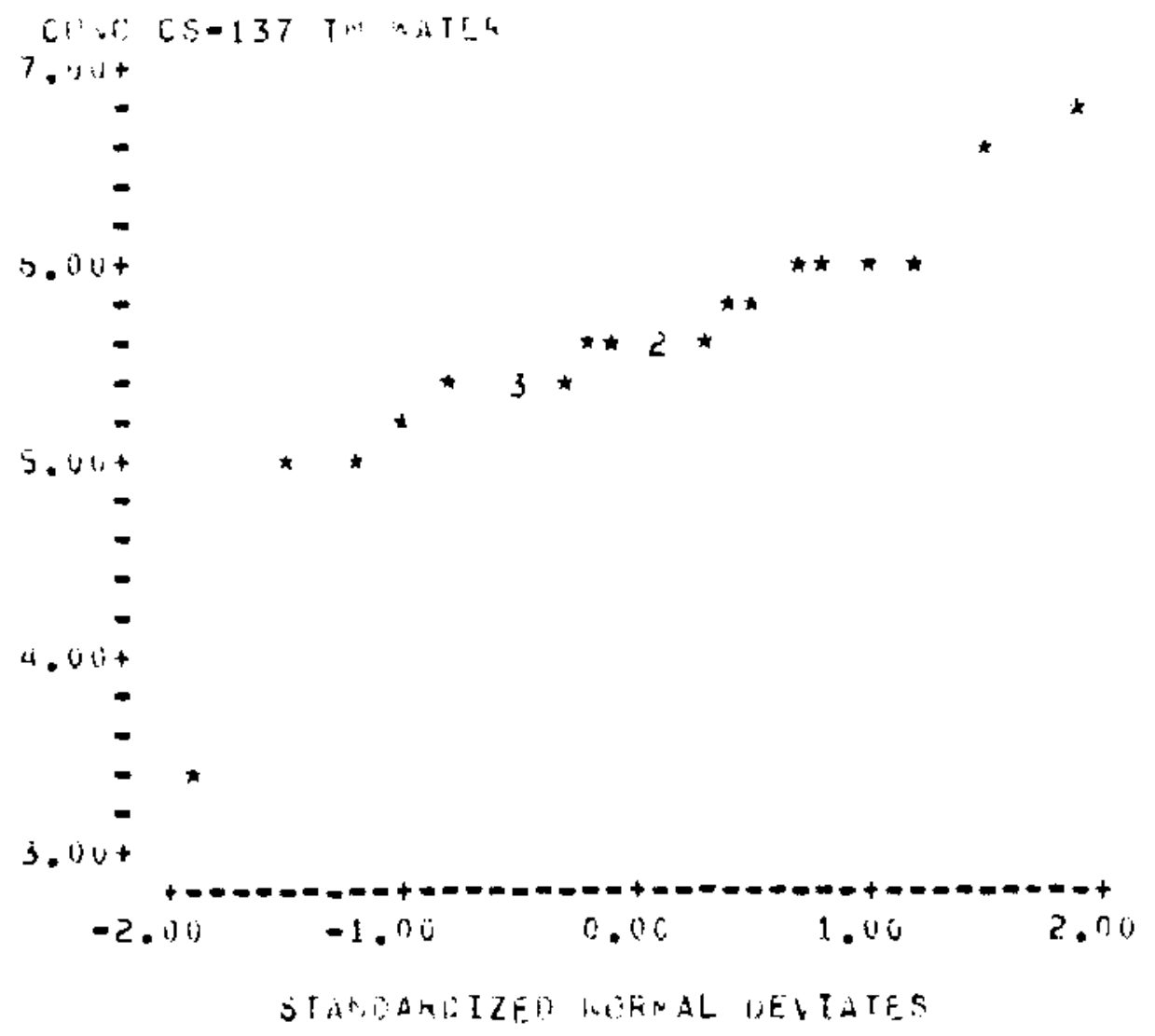

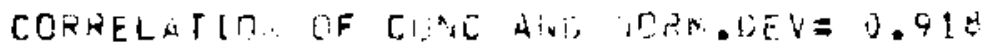




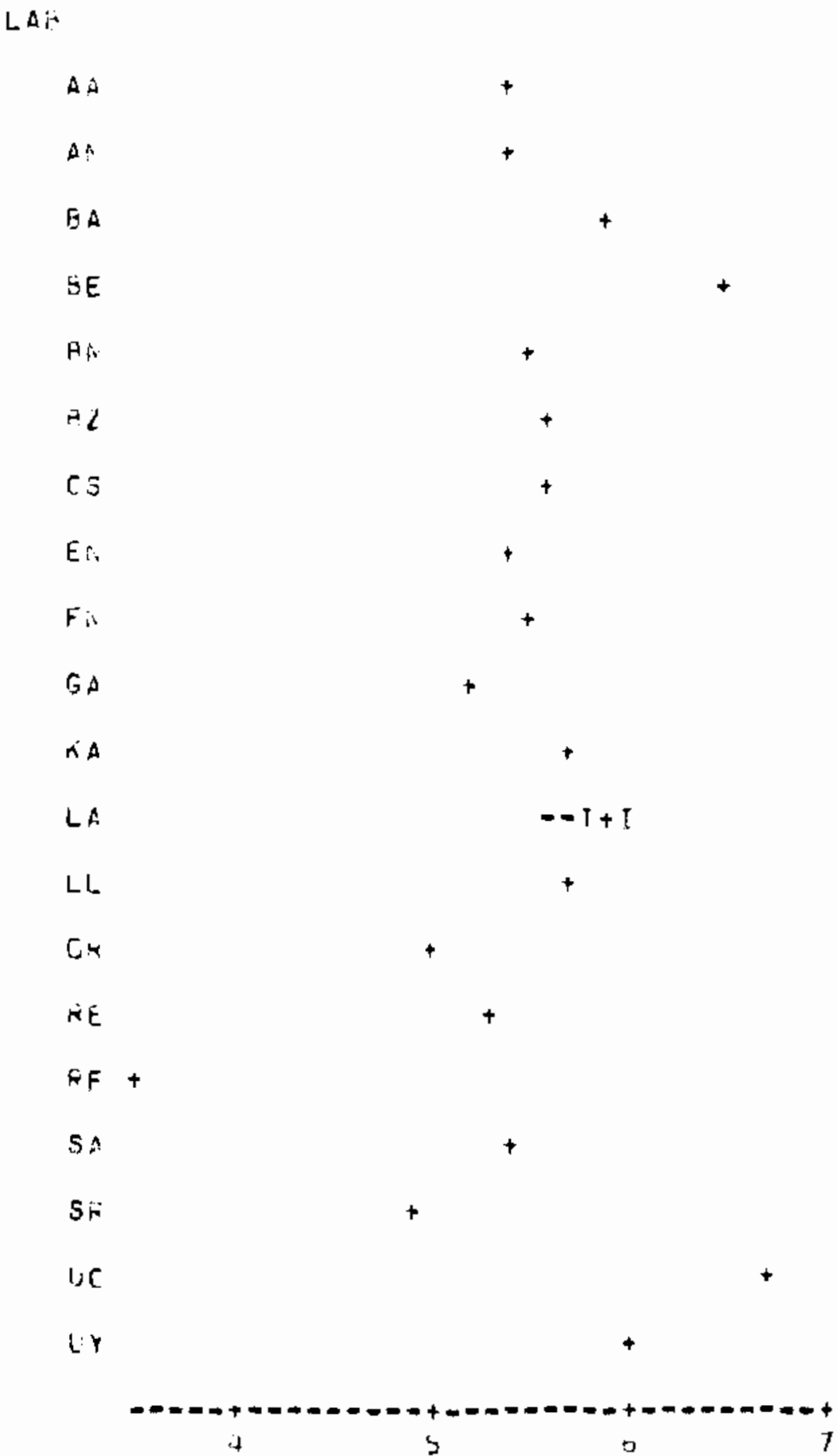

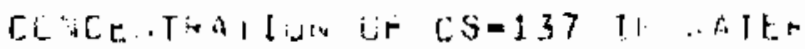

A. 16 
PNL -5079

UC-41

\section{DISTRIBUTION}

No. of

Ceples

OEESITE

5 S. P. Mathur

Office of Operational Safety

Public Safety Division

Ma11 Stop J-125/PE-243

U.S. Department of Energy

Washington, D.C. 20545

M. V. Sastry

Office of Operational Safety

Ma11 Stop G-150/PE-21.1

U.S. Department of Energy

Washington, D.C. 20545

C. Sanderson

U.S. Department of Energy

Environmenta] Measurements Lab

376 Hudson Street

New York, NY 10014

W. E. Keheley

U.S. Department of Energy

San Francisco Operations Office

1333 Broadway

Oak1 and, CA 94612

Mr. D. Mercer

U.S. Department of Energy Albuquerque Operations office

P.0. Box 5400

Albuquerque, NM 87115

Jerry J. Nelsen

U.S. Department of Energy

Environmental Protection Group

9800 South Cass Avenue

Argonne, IL 60439

Jeffrey M. Steele

Office of Naval Reactors

Mail Stop NE-60

Wash ington, D.C. 20585
No. of

Ceples

\section{QEFSITE}

Stanley S. Stief

U.S. Department of Energy

Environmental Protection Branch

P.0. Box E

Oak Ridge, TN 37830

M. Marcy Wtilianson

U.S. Department of Energy

Radiological and Environmental Sciences Laboratory

550 Second Street

Idaho Fal1s. ID 83401

S. R. Wright

U.S. Department of Energy

Savannah River Operations Office P.0. Box A

Aiken, SC 29801

27 DOE Technical Information Center

\section{ONSITE}

2 DOE Richland Operations Office

D. R. ElTe

H. E. Ransom/P. K. Clark

\section{Pacific Northwest Laboratory}

J. B. Brown

R. E. Jaquish (38)

W. E. Kennedy, Jr.

R. R. Kinnison

L. J. Kirby

K. R. Price

R. G. Schreckhise

Publishing Coordination (2)

Technical Information (5) 
